\title{
Ceramide Metabolism Balance, a Multifaceted Factor in Critical Steps of Breast Cancer Development
}

\author{
Victor García-González * (D), José Fernando Díaz-Villanueva, Octavio Galindo-Hernández ${ }^{(\mathbb{B} \text {, }}$ \\ Israel Martínez-Navarro, Gustavo Hurtado-Ureta ${ }^{(1)}$ and Abril Alicia Pérez-Arias \\ Departamento de Bioquímica, Facultad de Medicina Mexicali, Universidad Autónoma de Baja California, \\ Mexicali 21000, Baja California, Mexico; jdiaz92@uabc.edu.mx (J.F.D.-V.); \\ octavio.galindo@uabc.edu.mx (O.G.-H.); israel.martinez.navarro@uabc.edu.mx (I.M.-N.); \\ gustavo.hurtado@uabc.edu.mx (G.H.-U.); abril.alicia.perez.arias@uabc.edu.mx (A.A.P.-A.) \\ * Correspondence: vgarcia62@uabc.edu.mx; Tel.: +52-68-6557-1622 (ext. 121); Fax: +52-68-6557-1622 (ext. 109)
}

Received: 23 July 2018; Accepted: 20 August 2018; Published: 26 August 2018

\begin{abstract}
Ceramides are key lipids in energetic-metabolic pathways and signaling cascades, modulating critical physiological functions in cells. While synthesis of ceramides is performed in endoplasmic reticulum (ER), which is altered under overnutrition conditions, proteins associated with ceramide metabolism are located on membrane arrangement of mitochondria and ER (MAMs). However, ceramide accumulation in meta-inflammation, condition that associates obesity with a chronic low-grade inflammatory state, favors the deregulation of pathways such as insulin signaling, and induces structural rearrangements on mitochondrial membrane, modifying its permeability and altering the flux of ions and other molecules. Considering the wide biological processes in which sphingolipids are implicated, they have been associated with diseases that present abnormalities in their energetic metabolism, such as breast cancer. In this sense, sphingolipids could modulate various cell features, such as growth, proliferation, survival, senescence, and apoptosis in cancer progression; moreover, ceramide metabolism is associated to chemotherapy resistance, and regulation of metastasis. Cell-cell communication mediated by exosomes and lipoproteins has become relevant in the transport of several sphingolipids. Therefore, in this work we performed a comprehensive analysis of the state of the art about the multifaceted roles of ceramides, specifically the deregulation of ceramide metabolism pathways, being a key factor that could modulate neoplastic processes development. Under specific conditions, sphingolipids perform important functions in several cellular processes, and depending on the preponderant species and cellular and/or tissue status can inhibit or promote the development of metabolic and potentially breast cancer disease.
\end{abstract}

Keywords: ceramides; meta-inflammation; breast cancer

\section{Introduction}

A chronic excess of triglycerides in the body, specifically within adipose tissue, can lead to its saturation and promote the release of free fatty acids (FFA) to blood circulation. These lipids could be transported by serum albumin and lipoproteins, promoting their accumulation in tissues such as liver, pancreas, and skeletal muscle, which triggers alterations in several signaling pathways associated with energetic metabolism and cell cycle regulation [1]. Importantly, saturated fatty acids (SFA) have been described as modulators of gene expression targets involved in the metabolism of sphingolipids [2]. For instance, the increase of cytoplasmic palmitoyl-CoA by lipogenesis and cell internalization could drive fatty acids toward ceramides synthesis in endoplasmic reticulum (ER) through the de novo pathway. Therefore, ceramides modify several metabolic pathways generating a cellular imbalance, for example C16 ceramide could block the activity of the electron transport chain (ECT) by inhibition 
of complex IV, inducing the generation of reactive oxygen species (ROS) [3]. In addition, an increase in mitochondrial ceramides contributes to the sensitization of the IP3R, favoring the release of $\mathrm{Ca}^{2+}$ from ER to the mitochondria [4].

Accumulation of triglycerides and intermediate molecules such as ceramides and diacylglycerols (DAGs) are a consequence of chronic overnutrition $[5,6]$. Therefore, DAGs, ceramides and SFAs induce chronic inflammatory conditions, originating cellular deleterious effects [7]. An increase in the synthesis of C16-ceramides is associated with obesity and development of diabetes mellitus type 2, inhibiting fatty acid oxidation [8] (Figure 1). Cytosolic DAGs are associated with activation of hepatic PKC $\varepsilon$ [9], which has been demonstrated to phosphorylate the insulin receptor (INSR) in Threonine-1160 leading to inhibition of IRS kinase activity [10]. Thus, activation of hepatic PKC $\varepsilon$ induced by DAGs in the pathogenesis of non-alcoholic fatty liver disease has been related to hepatic insulin resistance [9]. In addition, activation of TLR-4 by palmytic acid could trigger a cascade of intracellular signaling mediated by phosphorylation of IkBa, which induces the activation of p50 and p65, and the expression of serin-palmitoyl acyltransferase (SPT), ceramide synthase (CerS) and dihydroceramide desaturase, key enzymes in the synthesis of ceramides [11]. Likewise, the increase in intracellular ceramides could trigger the activation of NOD-like receptor family pyrin domain containing 3 (NLRP3) [12], complex that integrates the inflammasome. Indeed, inflammasome functions as a putative sensor of ceramides; therefore caspase- 1 is activated by this mechanism [13]. Evidence shows a close relationship among the role of ceramides with the development of metabolic pathologies (Figure 1).

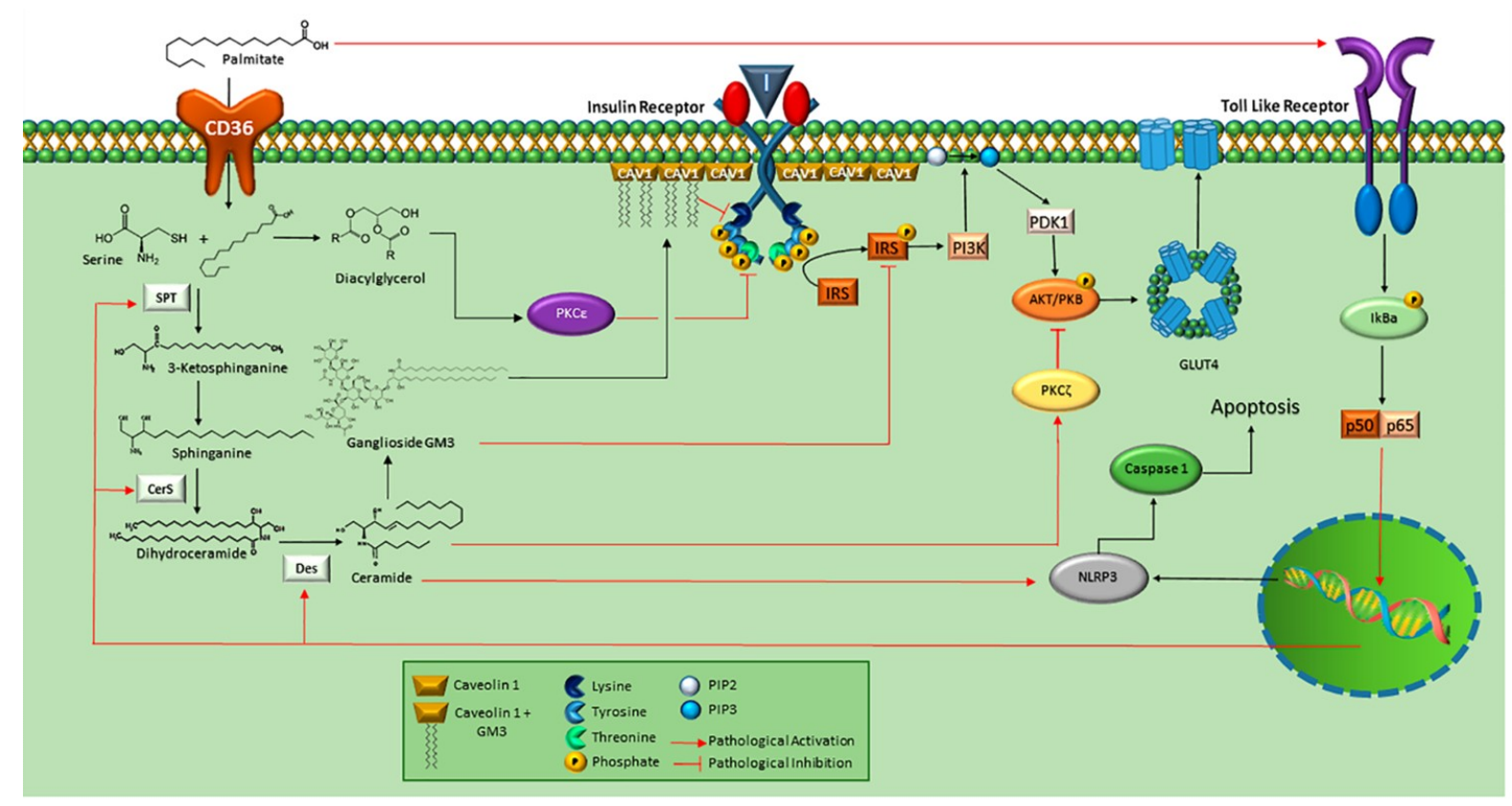

Figure 1. Metabolic implications associated to ceramide synthesis. Free fatty acid (FFA) such as palmitic acid is internalized through CD36, and ceramide synthesis is stimulated by serin-palmitoyl acyltransferase (SPT) through the addition of serine to produce sphinganine. Then, is converted into dihydroceramide by CerS and finally to ceramide by Des. Ceramides promote inhibition of Akt/PKB signaling by PKC function. Ceramides can be turned to GM3 which inhibits INRS, blocking insulin signaling. GM3 accumulation promotes the dissociation of IR/Cav-1 complex. Likewise, palmitic acid can function as a ligand for TLR-4, activating its signaling cascade that leads to the expression of genes encoding enzymes such as SPT, CerS, and Des. On the other hand, palmitic acid can be metabolized to DAG, which stimulates PKC , activated PKC $\varepsilon$ phosphorylates Thr 1160 of INSR, causing its inhibition. Finally, ceramides could activate NLRP3 and lead to apoptosis by Caspase-1-dependent pathway. Image adapted from references: [9-13]. 
In addition, an increase in the synthesis of ceramides associated with ER stress promotes the flow of lipids among ER and mitochondria through the structures such as mitochondria-associated ER membranes (MAMs) and multivesicular endosomes (MVEs), moreover these structures are involved in mechanisms such as ceramide synthesis, ATP flux between ER and mitochondria, as well as exosome-secretion [14]. In an important way, exosomes are vesicles that perform key functions in processes of autocrine, paracrine and endocrine communication. Specifically, MVEs are composed of intraluminal vesicles and participate in internalization of macromolecules and vacuolar/lysosomal hydrolase delivery [15]. Once molecules are incorporated in these vesicles, they have two pathways, degradation or secretion as exosomes by fusion with the plasma membrane, a process that is regulated by the endosomal sorting complex required for transport (ESCRT-I). Indeed, exosomes have been described to be enriched in ceramides; consequently, exogenous treatment with a sphingomyelinase inhibitor reduced the releasing of exosomes, as well as in the depletion of neutral sphingomyelinase-2, which suggests that ceramide metabolism is implicated in biogenesis of exosomes from intraluminal vesicles [14]. Furthermore, has been described that MVEs formation, and consequently, exosome secretion can be related with breast cancer, phenomenon proposed as a cellular stress response [16].

Ceramides play critical roles in the alteration of membrane structures, for instance, these lipids are a factor that triggers the formation of channel-like structures in the outer mitochondrial membrane (OMM), modifying conditions such as permeability and ionic concentration; thus, these conditions could facilitate the flux of pro-apoptotic proteins such as cytochrome-C, Smac/Diablo, and Omi/HtrA2, molecules of apoptosis intrinsic pathway. Paradoxically, ceramides function in apoptosis development has allowed a more complex visualization of them, such as their role in cell differentiation and proliferation signaling pathways $[17,18]$. Ceramides have been described as regulatory lipids that modulate various sides of cell growth, survival, senescence, and apoptosis in cancer $[19,20]$. Wherein, a correlation between the levels of ceramides and the tumor stage has been demonstrated, ceramides metabolism has also been associated to chemotherapy resistance $[19,20]$. Then, ceramides play important roles in the regulation of cancer progression, and are linked to their function in meta-inflammation, a condition that associates overnutrition and obesity with a chronic low-grade inflammatory state [21,22], representing a key factor in the regulation of pathological processes. Therefore, in this work, we performed an analysis of the state of the art about the multifaceted role of ceramides in several pathological processes, with a focus on lipid metabolism and breast cancer.

\section{Pathways of Ceramide Synthesis}

Ceramide synthesis can be carried out by means of hydrolysis of sphingomyelin, de novo synthesis, and the salvage and recycling pathway; therefore, there is a continuous flux of these lipids in cells. For instance, de novo synthesis is activated by increased saturated fatty acid accumulation, wherein palmitoyl-CoA and serine are conjugated by SPT, producing the unstable molecule 3-ketosphinganine, which is rapidly converted to dihydro-sphingosine that undergoes $\mathrm{N}$-acylations by the CerS, producing dihydroceramides. The function of CerS is considered a critical regulatory step, localized in ER and nuclear envelope. Later, the dihydroceramides are transformed by the dihydroceramide desaturase (DES 1 and 2) into ceramides. Subsequently, ceramides are delivered to the Golgi apparatus by vesicle transport, or through carrier proteins such as ceramide transfer protein (CERT) $[23,24]$, which is the only described protein capable of transferring vesicle-independent ceramides among organelles [25].

CerS are composed of six variants whose function lies in the condensation of acyl-CoA of different lengths to its sphinganine. Differences among CerS variants are associated with transmembrane topology, specificity for long chain fatty acids, and tissue distribution [26], each CerS changes during development and is expressed according to the cell type [26]. CerS1 and CerS4 generate C18-C20 ceramides, CerS5 and CerS6 generate C14-C16 ceramides, CerS2 selectively generates C22-C24 ceramides [27,28], and CerS3 mediates the synthesis of very-long chain C28-C32 ceramides with 
polyunsaturated fatty acids [29]. The activity of each CerS is determined by different post-translational modifications, as well as homo and heterodimerization.

Sphingomyelin is the main sphingolipid constituent of the plasmatic membrane, and ceramides generated by this pathway are produced by the hydrolysis of the phosphocholine head by the action of sphingomyelinase (SMase), which can be activated by extracellular signals such as oxidative stress, inflammation, and ionizing radiation [23]. Likewise, the salvage pathway can be activated by oxidative stress, this process begins in lysosomes or late endosomes wherein sphingomyelin and glycosphingolipids are hydrolyzed by the acid sphingomyelinase and $\beta$-glucosidase- 1 , respectively. Sphingolipids are released from these structures in the form of sphingosine and fatty acids, reaction catalyzed by acid ceramidase, this pathway could be regulated by PKC $\delta$ which activates sphingomyelinase. Furthermore, the recycling pathway involves deacylation of exogenous short chain ceramides by ceramidase to produce sphingosine, these pathways converge to obtain a product in common: ceramide produced by ceramide synthase [30]; likewise the recycling pathway has been involved in apoptosis [31]. Evenmore, gangliosides can function as precursors of ceramides, through the function of plasma membrane sialidase, to become sialosyl lactosyl ceramides [23].

Importantly, ceramide synthesis is activated by different cellular stimuli, including increased intracellular concentration of postprandial palmitate, hypoxia, intracellular stress, activation of the neutral sphingomyelinase [24,25], as well as inflammatory stimuli mediated by TLR-4 in response to TNF $\alpha$ and INF $\gamma$ signaling, inducing the expression of enzymes such as SPT [32]. Therefore, the activation of ceramide synthesis due to meta-inflammation as a result of overnutrition, could generate a deleterious circle by the activation of proinflammatory and pro-apoptotic signaling in metabolic tissues, modifying organelles structure, then the pathological state is amplified [33].

\section{Ceramides, Association with Endoplasmic Reticulum and Mitochondria}

Ceramide hydrophobicity represents an energetic barrier that prevents free movement among membrane structures; for instance, communication of ER and mitochondria requires physical contact of membrane proteins that facilitate the flow of molecules. Within structure of MAMs, enzymes involved in lipid biosynthetic pathways of ceramides and glycosphingolipids have been described, for instance, ceramide synthase, ceramide glucosyltransferase, glucosylceramide galactosyltransferase, and sialyltransferase [34]. Physiologically, there is a 5-20\% area of contact between ER and mitochondria, which suggests a considerable flow of molecules between these organelles $[35,36]$ (Figure 2). 


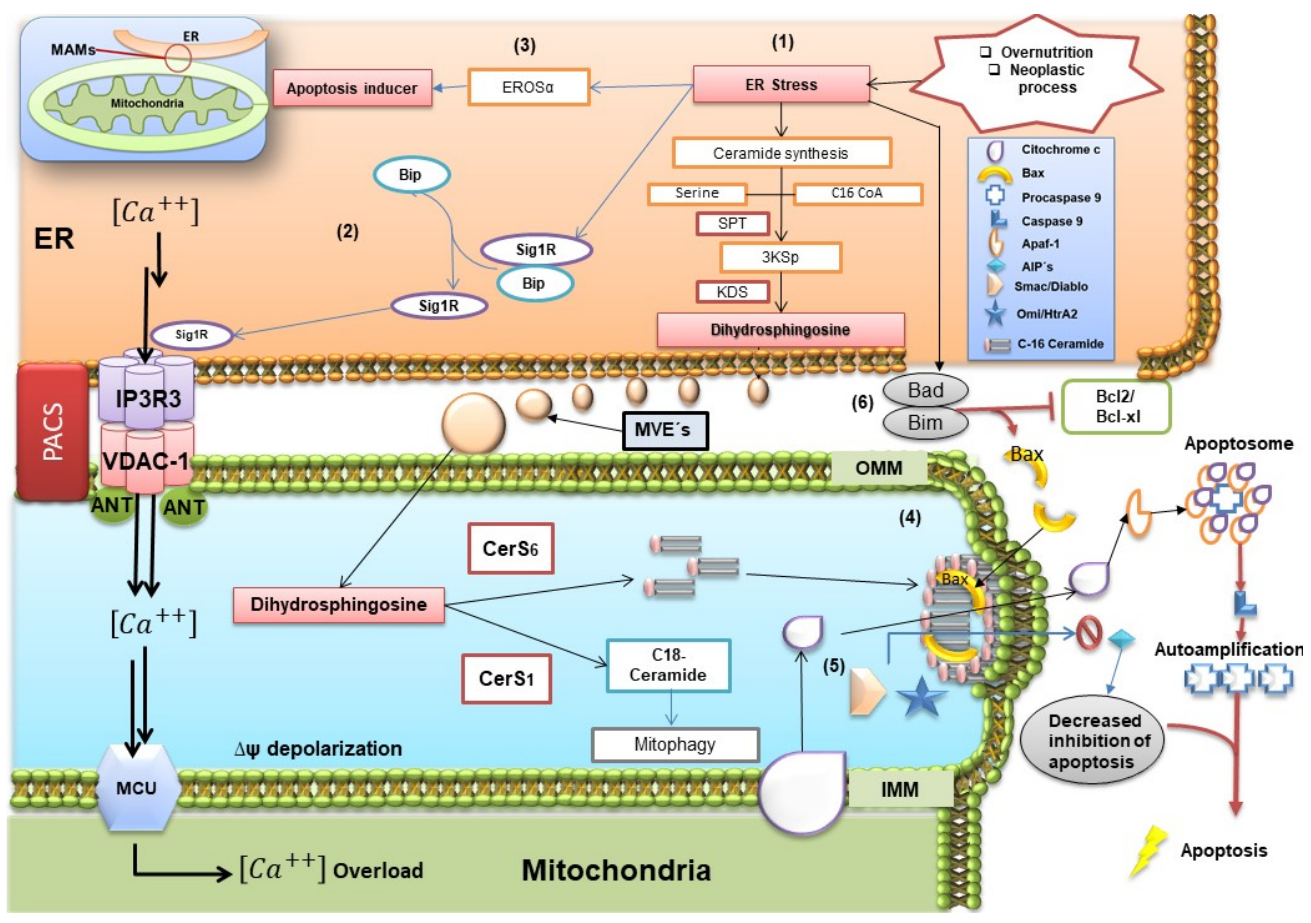

Figure 2. Overview of endoplasmic reticulum (ER) and mitochondria interactions. ER stress phenomenon promotes the activation of the de novo ceramide pathway, producing an increase in the exportation of dyhidrosphingosine and enzymes such as CerS1 and CerS6 through mitochondria-associated ER membranes (MAMs) or multivesicular endosomes (MEVs) to mitochondria (1), this originates the cleavage of Sig1R/Bip complex, Sig1R binds to IP3R3/VDCA-1 allowing the flow of $\mathrm{Ca}^{2+}$ through the ER to the inter-membranal space of the mitochondria by MCU (2), it can cross the inner mitochondrial membrane, producing a supersaturation in the mitochondrial matrix. This condition facilitates the activation of apoptosis by means of CHOP-dependent EROS $\alpha$ (3). In inter-membrane space, C16 ceramide leads to synthesis and assembly of pores that synergistically with Bax are translocated to OMM (4), this modifies the permeability of the membrane and allows the output of cytochrome C and proteins as SMAC/DIABLO and Omi/Htra (5). Later, cytochrome-C is associated with Apaf-1, promoting the change from procaspase- 9 to caspase-9, leading to apoptosome formation. The complex Bad/Bim inhibits the antiapoptotic action of Bcl-2 and Bcl-xL, which in turn are associated with preventing the oligomerization of Bax with the pores, as well as inhibition of cytochrome C release (6). Image adapted from references: [4,14,18,37-39].

ER-mitochondria associations are not only restricted to synthesis and lipid flow: even more mitochondrial ATP transfer to the ER is critical for chaperone function in the activity of unfolded protein response (UPR). One of chaperones, BiP (Grp78), recruits the adaptor protein TRAF2 in cytoplasmic domains and activate ASK-1 and JNK kinase, which could target mitochondria through various signaling pathways such as phosphorylation of Bim, and Bad [40,41], proteins of the Bcl-2 family involved in cell progression pathways and apoptosis [42]. In an important way, by decreasing the fluidity of the mitochondrial membrane, ceramides attenuate the stability of MAMs, which are structures needed for tumor cells adaptation under conditions of metabolic stress [43] (Figure 2).

In this sense, phosphofurin acidic cluster sorting protein 2 (PACS-2) is implicated in ER-mitochondria tethering, which regulates MAMs formation [37]. The function of PACS-2 is dependent of Akt phosphorylation (Figure 2), which enables PACS-2 to be retained in MAMs [44]. Likewise, PACS-2 interacts with calnexin, a regulator of ER-mitochondria $\mathrm{Ca}^{2+}$ flux $[45,46]$, and blocks BAP31 processing mediated by caspase 8 [37]. This interaction is the basis of PACS-2-mediated ER-mitochondria tethering, wherein BAP31 interacts with the mitochondrial Drp1 docking protein Fis1 [47]. However, this complex is associated with procaspase- 8 under conditions of cell stress 
where the mature form of caspase-8 triggers the formation of the BAP31 p20 fragment, an activator of mitochondrial fission [48]. Likewise, in cytoplasm, p53 can be located within the MAMs, wherein a fraction of p53 could stimulate the activity of the Sarco/ER Ca ${ }^{2+}$ ATPase pump, regulating $\mathrm{Ca}^{2+}$ levels in ER. In fact, under pro-apoptotic conditions, its downward activity causes an overload of $\mathrm{Ca}^{2+}$ inside the mitochondria, which is a factor of formation of mitochondrial permeability transition pores [4].

Intracellular increase of ceramides modifies several signaling pathways that maintain cell homeostasis [49]. For instance, longer acyl chain ceramides decrease membrane fluidity of mitochondria [50]. Specifically, the presence of two species of ceramides $\mathrm{N}$-acetyl-D-erythro-sphingosine $\mathrm{C} 2$ and $\mathrm{N}$-palmitoyl-D-erythrosphingosine $\mathrm{C} 16$, has been associated together with other proteins to formation of channel-like structures, then increasing permeability of OMM. These structures could facilitate the movement of proteins from the inter-membrane space to the cytoplasm, such as the inducing factor of apoptosis, cytochrome $C$, procaspases, and several heat shock proteins [51,52]. Nevertheless, this proposal has been questioned; moreover, Lee et al. (2011) [53] propose that ceramides facilitate the effect of Bax, a pro-apoptotic protein, which directly could trigger the pore formation on OMM [53].

Experimentation on mitochondria of hepatocytes deleted of Bax showed increasing levels of cytochrome $\mathrm{C}$ releasing under Bax treatment than stimulation with $\mathrm{C} 16$ ceramide alone, even at high doses. In addition, minimal doses of $\mathrm{C} 16$ ceramide and recombinant Bax, potentiated the release of cytochrome $\mathrm{C}$. Therefore, $\mathrm{C} 16$ ceramide is not considered a direct inducer of increased permeabilization of OMM, while it improves the insertion of Bax on OMM [53]. Although the release of these proteins promotes the activation of several caspases and DNases, other mitochondrial effects appear, such as the increase in ROS, alterations in calcium homeostasis of MAMs, modifications of several components of the ECT, as well as reduction in ATP concentration with the consequent collapse of inner mitochondrial membrane (IMM) potential.

While ceramides are lipids capable of inducing the destabilization of OMM, leading to increased membrane sorting and inducing gel/fluid phase separation possibly to form channels, the characterization of these channel-structures shows that only proteins could have the stability to form these structures. Considering that pore formation, as the main mechanism of mitochondrial permeabilization, has been questioned due to a thermodynamic barrier. Even more, the concept of an increased permeability induced by a surface mismatch between the two mitochondrial monolayers has been proposed [54]. Notwithstanding, in vitro studies with liposomes treated with C16 ceramides and supported by electron microscopy and molecular dynamic simulations, have suggested the pore structure formation [55]. In this proposal, ceramide molecules are organized in columns arranged in anti-parallel way originating a cylindrical shape spanning the hydrophobic interior of the OMM $[52,56,57]$. These phenomena could be dependent on the long chain and the degree of unsaturation of acyl chain of ceramides [4,38]. Nowadays, the debate on the proposal that explains this process in function of thermodynamic feature, still remains.

Likewise, in mitophagy, a physiological process in which cells eliminate dysfunctional mitochondria, ceramides have been described that induce mitophagy, targeting mitochondria that contains LC3B-II autophagolysosomes [58]. Specifically, C18 ceramides have emerged as tumor suppressors. CERS1 expression generating C18 ceramides mediates the localization of ceramide on the OMM, leading to mitophagy. Target mitochondria through LC3 - an important component in the formation of autophagosome which is conjugated with phosphatidyl-ethanolamine through the C-terminal domain forming LC3B-II [58,59] — binds ceramides on the mitochondrial membrane upon DNM1L/DRP1, leading to inhibition of mitochondrial function and oxygen consumption [58]. In this sense, the interaction LC3B-II-ceramide involves the central hydrophobic domain of the protein [60].

\section{Role of MAMs in Neoplastic Pathology}

The role of MAMs has been considered a fundamental feature of the anti-apoptotic effect in neoplastic cells, mainly due to the control of $\mathrm{Ca}^{2+}$ flux, and the handling of ROS balance, generated 
by uncontrolled growth and/or antineoplastic therapy [43]. Moreover, the localization of oncogenic and/or tumor suppressor proteins in these special areas of contact ER/mitochondria, participating in the physiological signaling pathways, have direct implications in the development of neoplastic pathology [43]. Currently, several mechanisms have been associated with the function of MAMs in several types of cancer, such as breast, lung, prostate, hematopoietic, and/or lymphoid neoplasias. For instance, the sigma 1 receptor (S1R) in normal tissue is associated with chaperone protein $\mathrm{BiP} / \mathrm{GRP78}$ within the area of MAMs [41]; in contrast under conditions of stress it is uncoupled from the BiP, to bind IP3R3, liberating $\mathrm{Ca}^{2+}$ from the ER to the MAMs. On the other hand, S1R is translocated under chronic stress towards the periphery of ER, and thereby attenuates the cell death signal that would generate $\mathrm{Ca}^{2+}$ overload in mitochondria and then, $\mathrm{ER} \mathrm{Ca}^{2+}$ depletion during chronic conditions [61].

MAMs perform microzones of anchoring enzymes that maintain oxidative homeostasis, such as endoplasmic reticulum oxidoreductase- 1 alpha (ERO- $1 \alpha)$, with which overexpression in tumor tissue is associated with poor prognosis [62]. In addition, a strong correlation among the levels of ERO- $1 \alpha$ and programmed cell death-ligand 1 (PD-L1) is proposed, allowing the escape of the immunological attack, and confining an immunosuppressive phenotype [63]. However, ERO-1 $\alpha$ also participates in cell death mediated by activation of compound 1 activator of procaspase (PAC-1), inducing apoptosis in several tumors [39]. In this sense, ERO- $1 \alpha$ shows a dual role in neoplastic pathology, previously mentioned in the implication of oxidative balance and the presentation of immuno-tolerance with anti-apoptotic characteristics, in contrast to cell death via activation of PAC-1 pro-apoptotic feature [39]. In addition, within the structure of MAMs, the PERK arm of UPR is localized [64], its deficiency showed an association with tumors of low proliferation, because PERK triggers mechanisms that maintain redox balance [65].

In colon and breast cancer, ATAD3 has been described as functioning in conjunction with GRP78 within the MAMs, to keep the stability of WASF3, one function of which is the activation of actin polymerization, participating in the metastatic phenomenon, and leading to a bad prognosis [66]. Interestingly, ATAD3 has been pinpoint in the vicinity of the lipid transfer zone between ER and mitochondria [67], the aforementioned is important for maintain the integrity of the lipid bilayer of the mitochondria [68,69]. In lung cancer, the expression of variants of the Bcl-2 family has been described, for instance the presence of Bcl-2 [70,71] and Bcl-XL [72] is associated with an anti-apoptotic phenotype in non-small cell lung carcinoma. On the other hand, myeloid cell leukemia-1 (Mcl-1), another member of the Bcl-2 family within MAMs, activates the voltage-dependent anion-selective channel 1 (VDAC-1), increasing the flux of $\mathrm{Ca}^{2+}$, then cell migration [73].

In addition, hexokinase-2 (H2K) is over-expressed in cancer cells, wherein glycolysis has been described to show an important role in the initiation and neoplastic development in models of mice with K-Ras driven lung cancer and Her2/Neu-driven breast cancer [74]. However, the phosphorylation of H2K dependent of Akt causes the translocation of H2K to the MAMs, wherein maintains interaction with VDAC-1, in this manner H2K takes advantage of the emerging ATP of the channel formed by VDAC-1, catalyzing the first reaction of glycolysis, in this way contributes to the Warburg effect [75], a metabolic adaptation to hypoxic microenvironment due to lack of blood supply, and fundamental in the survival neoplastic during early stages.

In this sense, lactate produced by anaerobic glycolysis in Warburg effect generates an acid microenvironment that activates the VEGF signaling pathway, a proper condition to tumor growing [76]. This hypoxic condition leads to activation of $\operatorname{HIF} \alpha$, which, in collaboration with c-Myc activate pyruvate dehydrogenase kinase 1 [77], reduces mitochondrial oxygen consumption and promotes anaerobic glycolysis, then lactate synthesis [78]. Recently, MAMs have been proposed as regulators of cancer cells metabolism due to their function in $\mathrm{Ca}^{2+}$ exchange between ER and mitochondria, which is needed for oxidative phosphorylation [79]. Therefore, alteration of MAMs could lead to modifications of $\mathrm{Ca}^{2+}$ exchange and ATP production [80]. Moreover, some proteins within the MAMs have been proposed as potential regulators of tumor cell metabolism, for instance, TMX1 is 
related with glycolysis and oxidative phosphorylation balance [80], mitofusin-2 as an important regulator on MAMs contact has been associated to pro-apoptotic and anti-proliferative signaling [81], and PACS-2 proposed as a tumor suppressor [82].

While MAMs connect membrane surfaces between mitochondria-ER, these associations harbor multiple enzymes and proteins, which allow cell homeostasis preservation and, thus, survival in neoplastic pathology [43]. MAMs represent a focus of therapeutic target for antineoplastic therapy, due to its associations with responses to oxidative stress and harmful microenvironments, favoring resistance to pro-apoptotic stimuli in cancer cells [83]. Indeed, the use of ceramides as coadjuvant therapy with different antineoplastics, is a novel treatment option due to its multifactorial participation in the structure and function of MAMs [84]. In line with this notion, ceramides are bioactive lipids that modulate processes such as proliferation and cell cycle, key events in the development of cancer $[19,20]$. Various reports have shown that cancer cells strictly modulate ceramide metabolism $[19,20,85]$. For instance, sphingolipid metabolism has been reported to regulate cancer development, progression, metastasis and resistance to therapy, some mechanisms have been described to explain how ceramides could regulate these processes specifically in breast cancer $[19,20]$.

\section{Ceramides and Breast Cancer}

Ceramide-1-phosphate and glucosylceramides regulate proliferative processes, while dihydrosphingosine, ceramides, and sphingosine promote apoptosis [19]. While, the effects of ceramides in various cell types are pleiotropic, functioning as inhibitors of cell proliferation, ceramide levels are down-regulated in most types of cancer via decreasing levels or activities of enzymes involved in ceramide synthesis, and/or increasing the activity of enzymes associated with degradation. For instance, in breast cancer cell lines, ceramides promote cell cycle arrest by mechanisms such as the induction of the dephosphorylation of the $\mathrm{Rb}$ retinoblastoma protein, the activation of the cyclin-dependent kinase inhibitor p21, and the inhibition of the cyclin-dependent kinase CDK2 [86,87], additionally to promotion of pore formation mechanisms in OMM [88]. Indeed, taking into account the inducer effect of apoptosis in breast cancer, ceramides are considered a tumor suppressor lipid $[86,89,90]$.

In this sense, acid ceramidase is an enzyme that deacylates ceramides in the ceramide metabolic pathway to sphingosine, which is further phosphorylated by sphingosine kinase (SphK) to generate sphingosine-1-phosphate (S1P). Interestingly, ceramides have been shown to induce apoptosis, whereas S1P could regulate cell survival, proliferation, and angiogenesis in cancer cells [19,91]. S1P is described to exert multiple responses, such as proliferation, survival, and cytoskeletal rearrangement, via its $G$ protein-coupled receptor (GPCR) in several cell types, promoting the activation of Rho and CDC42 GTPases, and MAPK, PI3K/Akt pathways. S1P is synthesized from sphingosine by SphK; two isoforms of mammalian SphK (SphK1 and SphK2) have been characterized. Likewise, the S1P has been shown to accumulate in the tumor microenvironment [19,92] (Figure 3).

Therefore, the role of sphingolipids in the development of breast cancer has been controversial, however cancer cells that maintain an active proliferation specifically present low levels of ceramides, by up-regulating enzymes that metabolize these lipids, resulting in conditions of resistance to apoptosis $[85,93]$. Previous studies described different expression profiles of the sphingolipids enzymes in cancerous tissue relative to normal tissue. Schiffmann et al. showed that endogenous ceramide level was significantly elevated in malignant breast tissue, indicating that elevation of sphingolipid levels correlates with disease status [94]. Particularly, the mammary tumor tissue showed high levels of C16:0-Cer, C24:1-Cer and C24:0-Cer in comparison with non-tumoral tissue, and this increase was associated with higher expression of ceramide synthases CerS2, CerS4 and CerS6. Interestingly, levels of C18:0-Cer and C20:0-Cer were associated with positive tumors for the estrogen receptor, while high levels of C16:0-Cer were linked with metastasis to lymph nodes [94,95].

On the other hand, increasing ceramide levels using ceramide analogs effectively induce apoptosis of breast cancer cells. The stimulation of breast cancer cell lines MCF7 and MDA-MB-231 with the 
analog of ceramide (2S,3R)-(4E,6E)-2-octanoylamidooctadecadiene-1,3-diol promotes apoptosis by translocation of phosphatidylserine to the outer monolayer of the cell membrane and deregulation of mitochondrial membrane potential and released of cytochrome $C[96,97]$. Therefore, ceramides have been proposed as a therapeutic target for specific types of cancer by synergism with several drugs, as potent tumor suppressors, and acting as second messengers in signal transduction and regulation of proliferation, differentiation, senescence, and apoptosis [85,93]. Chemotherapeutic drugs can induce the endogenous accumulation of ceramides, promoting cancer cells apoptosis, evidence suggests that modulation in the lipid metabolism may be effective to improve tumor cells susceptibility to antineoplastic drugs. Indeed, several chemotherapeutic agents increase the synthesis of ceramide through the activation of SMases or de novo pathway, such as gemcitabine, camptothecin, etoposide, cisplatin, fludarabine, and daunorubicin $[98,99]$. Furthermore, anti-tumoral treatment modulates the expression of the receptors for S1P. In MCF7 breast cancer cells, tamoxifen and medroxyprogesterone treatment induces an increase of S1P2 expression, while this same treatment induces a down-regulation of S1P3 [100]. However, the biological mechanism that causes this phenomenon has not been described. For instance, treatment of P388 and U937 leukemia cells with daunorubicin promotes apoptosis by increasing ceramide levels by de novo pathway [101]. Subsequently, in the next chapters we are going to analyze the critical steps in cancer progression and the role of ceramide metabolism.

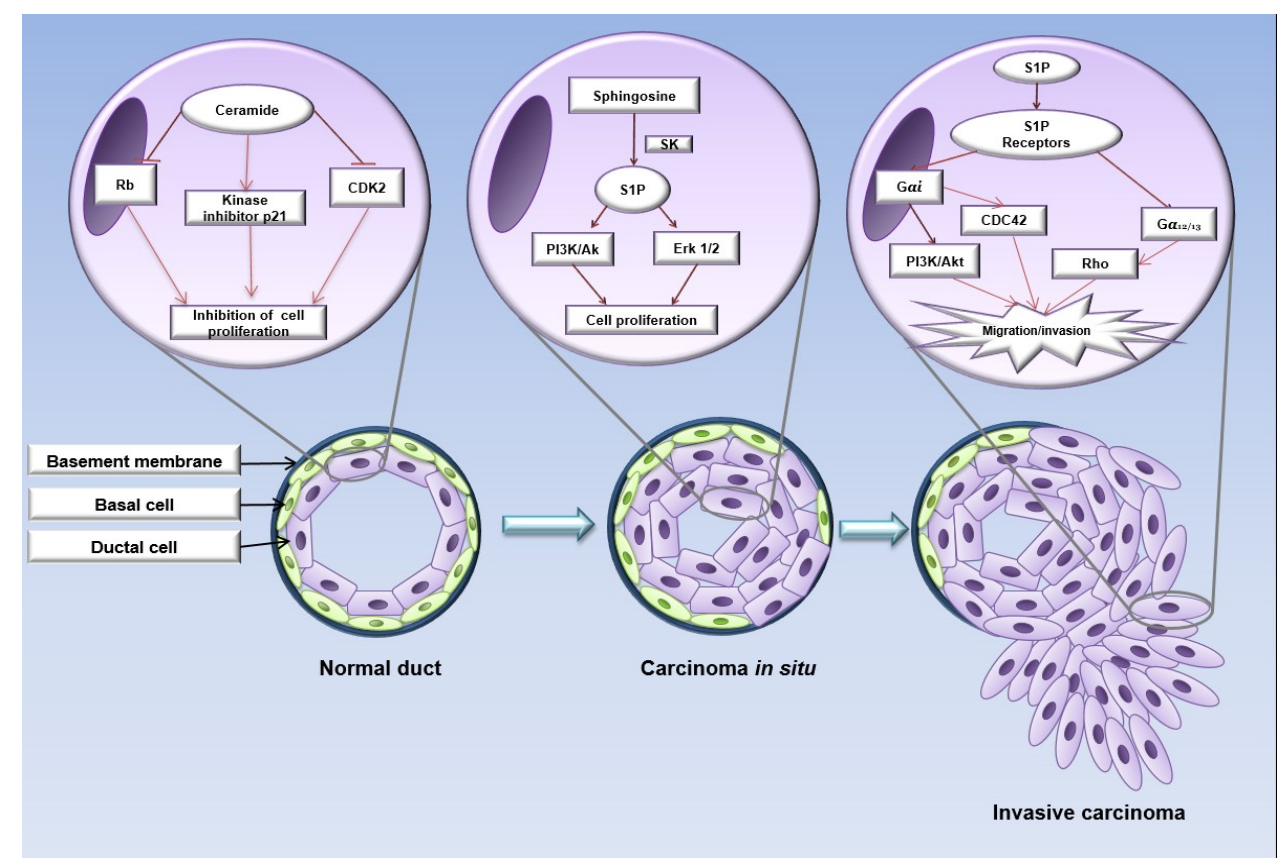

Figure 3. Schematic view of sphingolipid role in breast cancer progression. Structurally, the mammary ducts are composed of basal membrane, a layer of myoepithelial cells and another of luminal ductal cells. In the normal mammary epithelium, ceramides negatively regulate the Rb and CDK2 proteins, inhibiting cell proliferation. In carcinoma in situ, luminal tumor cells present an abnormal metabolism of ceramides, where sphingosine-1-phosphate (S1P) through S1PR promotes activation of the PI3K/Akt and MAPK pathways, inducing cell proliferation. The loss and/or degradation of the basement membrane allow the tumoral cells to migrate and invade the surrounding tissue. In this stage, S1PR promotes GTPases activation such as Rho and CDC42, inducing tumor invasion and consequently, metastasis. Image adapted from references: [12,19,92,102].

\section{Involvement of Ceramides and Sphingolipids in the Epithelial-Mesenchymal Transition (EMT)}

EMT is an important process involved in embryonic development, wound healing, fibrosis, and breast cancer metastasis $[103,104]$. The EMT process implies that epithelial cells progressively 
acquire a mesenchymal phenotype. It is characterized by a decrease in E-cadherin and cytokeratin (CK) 8/18 levels, loss of apical-basal polarity, junctions dissociation, cytoskeleton reorganization, an increase in N-cadherin and vimentin levels [103], as well as matrix degradation and an enhanced ability for cell migration and invasion. Cells that have undergone all these modifications have transitioned from an epithelial to a mesenchymal phenotype $[103,104]$.

For instance, in mouse mammary epithelial cells under the EMT process, a modulation in the metabolism of gangliosphingolipids has been determined. Galp $\beta 1-3$ GalpNAc $\beta 1-4$ Galp $\beta 1-4 \mathrm{Glcp} \beta$ $(\mathrm{Gg} 4)$ is involved in the regulation of EMT, since the concentration of this lipid is reduced in transdifferentiate cells into mesenchymal cells. In addition, Gg4 forms complexes with proteins such as E-cadherin and $\beta$-catenin, preventing its degradation and favoring the epithelial phenotype [99]. Additionally, the differential expression of enzymes related to the ganglioside metabolism observed in EMT is associated with the regulation of transcription factors such as Snail1, ZEB1, and Twist, key EMT-inducing proteins [105].

Likewise, mammary epithelial cells under EMT showed a decrease in the levels of Ceramide C16:0, as well as CerS6. Mammary epithelial cells treated with TGF- $\beta$ have decreased levels of CerS6, a phenomenon observed in patients with triple negative breast cancer (TNBC) mesenchymal cells [106]. The decrease of C16:0 ceramide levels in patients with TNBC are associated with migratory and invasive capacity of tumor cells. In addition, the down-regulation of CerS6 in tumors is associated with mesenchymal phenotype, as well as aggressive malignancies and poor prognosis [106].

As previously described, S1P is a bioactive lipid that regulates several responses including inflammation, survival, and cell migration [102]. Forming complex with their respective receptors (GPCRs), S1P promotes the activation of non-receptor kinases such as FAK, Src, as well as GTPase Rac, regulatory proteins of cell migration and invasion [102]. In human mammary non-tumorigenic epithelial cells MCF10A, a cellular model for the study of EMT, treatment with S1P induces the activation of the S1P3 receptor, promoting the activation of Erk $\frac{1}{2}$, Rac, Akt, and PI3K, and an increase in the expression and secretion of MMP-9. Moreover, S1P induces an increase in migratory and invasive capacity of mammary epithelial cells, promoting an EMT-like process in MCF10A cells [102] (Figure 4).

Recently, a study performed in human breast cancer patients showed that ceramide levels are elevated in breast tumor tissue compared to adjacent tissue and/or non-tumor tissue [90]. In addition, the enzymes involved in the de novo pathway, in the salvage and the sphingomyelin pathways are overexpressed in cancerous tissues, accompanied by an increase in the levels of multiple ceramides (C14: 0, C16: 0, C18: 1, C18: 0, C20: 0, C22: 0, C24: 1, C24: 0, C26: 1 and C26: 0), increase in the levels of monohexocylceramide species (C14: 0, C16: 0, C18: 1, C18: 0, C20: 0, C22: 0, C24: 1, C24: 0, C26: 1 and C26: 0), and an increase in sphingomyelin levels (C14: 0, C16: 0, C18: 1, C18: 0, C20: 0, C22: 0, C24: 1, C24: 0, C26: 1 and C26: 0), as previously mentioned these are related with an aggressive phenotype [90].

Interestingly, the metabolism of ceramides is associated with invasiveness and metastasis. For example, key regulatory enzymes in the ceramides and sphingolipid metabolism such as glucosylceramide synthase [26,107], acid ceramidase [108,109], and ceramide kinase [110,111] are overexpressed in mammary tumor tissue and/or breast cancer cell lines, suggesting a strong association between ceramides and their intermediates on tumor progression. Therefore, this broadens the understanding of the role of this class of lipids.

\section{Ceramides and Sphingolipids and Their Implication in Breast Cancer Metastasis}

In mammary tumor progression, the development of new blood vessels, denominated tumor angiogenesis, is a critical process. In this sense, S1P and S1P receptors have been described as key regulators of this process [112]. It has been shown that S1P induces an increase in intracellular calcium concentrations and migration of HUVECs cells through the activation of the S1P receptor [113]. Additionally, S1P promotes an increase in the proliferation and chemotaxis of HUVEC cells accompanied with enhanced in vitro angiogenesis $[113,114]$. This data confirms the involvement 
of molecules such as S1P and its receptors as modulators of angiogenesis and reflects its importance in tumor vascularization.

Considering the importance of ceramides in the regulation of multiple tumor processes, recently the ceramide nanoliposomes effect on mammary tumor cells cultures has been described. In MDA-MB-231 cells, the treatment of C6 ceramides encapsulated in liposomes (ceramide nanoliposomes) was able to significantly increase apoptosis under non-adherent conditions (anoikis), accompanied by an increase in caspase $3 / 7$ activity [115]. In addition, the ceramide nanoliposomes promoted a decrease in cell migration, associated with a diminution in the secretion of IL-6 and IL-8 in MDA-MB-231 cells [115].

Therefore, the interrelation between growth factors and the metabolism of sphingolipids in breast cancer cells has been demonstrated. For example, it has been shown that the treatment of MCF7 mammary tumor cells with epidermal growth factor (EGF) promotes an increase in the expression of sphingosine kinase 1, an enzyme required for cell proliferation and migration [116,117]. Interestingly, in the same cell line, the oestrogen-induced transactivation of EGFR depends on the sphingosine kinase pathway and S1P, a process accompanied by the activation of Src and matrix secretion of metalloproteinases, proteins highly involved in the regulation of migration, invasion, and tumor metastasis [117].

Finally, it is important to highlight the differences between events regulated by ceramides, sphingolipid-metabolites, and S1P. For instance, the presence of high levels of ceramides and their producing enzymes (CerS2) leads to a decrease in the secretion and activity of metalloproteinases, resulting in poorly invasive phenotypes of breast cancer cell lines [118]. In the other hand, the role of $\mathrm{S} 1 \mathrm{P}$ as a modulator of cell invasion and metastasis has been demonstrated. In human glioblastoma cells, S1P induces an increase in the secretion and activity of metalloproteinases, leading to the degradation of extracellular matrix, invasion of local tissue and finally, metastasis [119]. Additionally, S1P receptors play an important role in breast tumor development. It has been determined that sphingosine-1-phosphate receptor $1\left(\mathrm{~S}_{1} \mathrm{P}_{1}\right)$ is over-expressed in multiple breast cancer cell lines, positively regulating processes such as tumor migration and invasion. In line with this notion, the down-regulation of $\mathrm{S} \mathrm{P}_{1}$ inhibits cell proliferation, colony formation, migration and invasion [120].

Studies show that sphingosine-1-phosphate receptor $3\left(\mathrm{~S}_{1} \mathrm{P}_{3}\right)$ is over-expressed in invasive breast cancer cell lines, resulting in an increase in the expression of COX-2 and in microsomal prostaglandin (PG) E2 synthase, accompanied by a high synthesis of PGE2 and favoring tumor metastasis [121]. $\mathrm{S}_{1} \mathrm{P}_{3}$ has been involved as a regulator of blood-brain barrier permeability. In the breast cancer brain metastasis, the surrounding astrocytes express high levels of $\mathrm{S}_{1} \mathrm{P}_{3}$, which regulates and promotes the secretion of CCL2 and IL-6, leading to the relaxation of endothelial cell adhesion and increases the permeability of the blood-brain barrier [122].

This data strongly suggests that the subtle balance between the metabolites and enzymes producing ceramides/sphingolipids in tumor cells leads to the modulation of mammary tumor progression, highlighting the role of these molecules and their receptors as potential targets for breast cancer intervention, specifically associated to metastasis.

\section{Exosome-Ceramides and the Role in Tissue Communication}

Extracellular vesicles are spherical structures surrounded by a bilayer lipid membrane that are found in several body fluids and are secreted by a wide variety of cell types, including tumor cells [123]. According to the International Society for extracellular vesicles, these structures are classified depending on their size and biogenesis in apoptotic bodies, microvesicles, and exosomes [124,125]. Particularly, the exosomes are originated from MVEs, presented average size of 30-100 nm. In different types of cancer, altered levels of exosome release are observed, and their number, composition, and cellular origin depend on the state of the disease [124]. Moreover, it has been shown that exosomes regulate processes of tumor progression, such as proliferation, migration, invasion, metastasis, immunosurveillance, and evasion [126], as well as resistance to chemotherapy, denoting them as 
an important feature in the study of breast cancer progression [123]. Once secreted, exosomes mediate intercellular communication in autocrine, paracrine, and endocrine pathways. The exosomes modulate the functions of target cells by interacting with surface proteins of vesicles with membrane receptors and being endocyted by the target cell. In this way, the target cells uptake the set of charged molecules present in the exosomes, resulting in modulation of the cellular responses [123,124]. For instance, exosomes secreted by glioma cells transport and transfer EGFRvIII, a constitutively active oncogenic form of EGFR, then acceptor tumor cells show an increase in cell proliferation and survival [127]. Several studies have shown that cancer cells resistant to doxorubicin and cisplatin release high amounts of these molecules through exosomes, therefore their release contributes to tumor cell survival [128,129]. Moreover, cancer cell-derived exosomes contain MMP-2 and MMP-9, enzymes that degrade components of the extracellular matrix, facilitating the invasion of tumor cells into the surrounding tissue (Figure 4) [130]. Furthermore a recent study shows that tumor-secreted exosomes could facilitate metastasis even for tumour cells that lack the capacity to metastasize and this could be regulated by their pattern of integrins expression [131].

Exosome-composition depends on the cells from which they originate, including proteins, nucleic acids (RNA, DNA), and lipids [123,132]. Interestingly, sphingolipids have been associated with the biogenesis and secretion of exosomes. Accumulation of sphingolipids and the high activity of sphingomyelin phosphodiesterase (SMase) generates an increase in levels of free ceramides, associated with the formation of exosomes $[124,125,133]$. Compared to their parental cells, exosomes secreted by various cell types are enriched with various bioactive lipids such as eicosanoids, fatty acids, ceramides, and sphingomyelin [134,135], therefore, these molecules can be transferred to the acceptor cells. For instance, it has been determined that sphingosine-1-phosphate receptor $2\left(\mathrm{~S}_{\mathrm{P}}\right)$ is secreted and transported in exosomes derived from MDA-MB-231 breast cancer cells. Indeed, the exosomes that transport $\mathrm{S}_{1} \mathrm{P}_{2}$ are taken-up by cancer-associated fibroblasts (CAFs), resulting in an increase in CAFs proliferation dependent on ERK $\frac{1}{2}$ signaling [136].

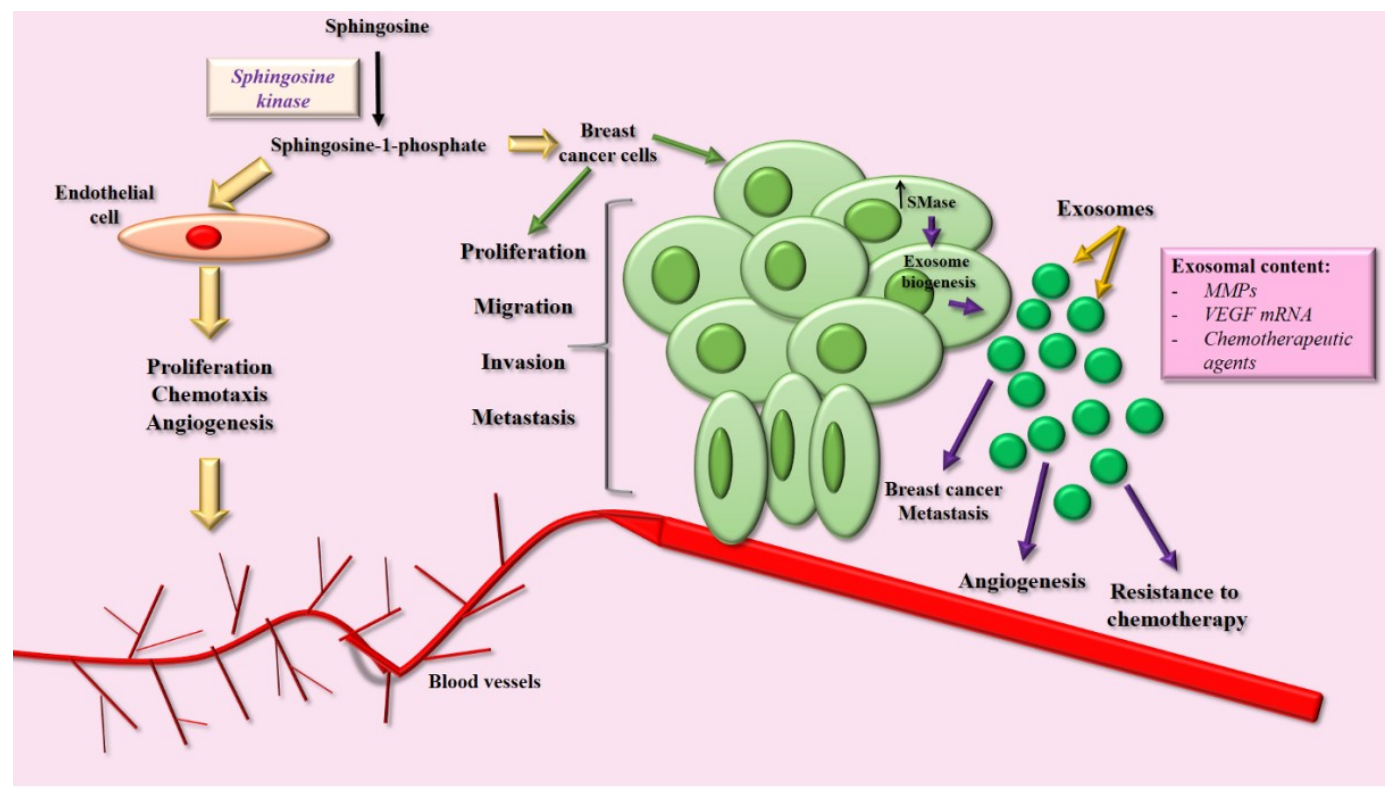

Figure 4. Ceramides and sphingolipids in breast cancer progression. S1P is a critical molecule involved in the modulation of angiogenesis. In endothelial cells, it has been demonstrated that S1P promotes proliferation, migration, and chemotaxis, resulting in the generation of intra-tumoral blood vessels that facilitate the process of metastasis. Moreover, S1P induces migration and invasion of breast cancer cells, promoting the process of tumor intravasation. Finally, in tumor cells, the SMase enzyme shows high activity, promoting the biogenesis and secretion of exosomes, extracellular vesicles that modulate angiogenesis, metastasis, and resistance to chemotherapy. Image adapted from references: [14,120,132,136]. 
In addition, S1P is associated with several cellular processes such as angiogenesis, cell growth, motility, and in an important manner can be contained and transported by lipoproteins, the high density lipoproteins (HDL) being the main carrier. Approximately $60 \%$ of circulating S1P is associated to HDL, likewise HDL can carry on other sphingolipids such as sphingomyelins and ceramides (C:24) [137-139]. HDL is known for its anti-atherogenic function due to its composition of apolipoproteins, among which ApoM is found, whose function is to bind to S1P [140]; both ApoM and S1P are synthesized and secreted by the liver [141]. Although S1P has been considered as a cardioprotective molecule, S1P is described as a possible mediator of HDL-dependent angiogenesis, due to its interaction with receptor $\mathrm{S}_{1} \mathrm{P}_{3}$, whose activation promotes the expression of VEGFR2 [142]. Therefore, S1P is a moonlighting molecule, although it has a cardioprotective role through angiogenesis activation, this same effect can be detrimental favoring tumor proliferation. In this sense, S1P3 has been found up-regulated in breast cancer cells, a condition associated to increased migration and invasion of metastatic cells induced by an inflammatory environment in a COX-2-PGE 2 -dependent pathway [121].

On the other hand, S1P is capable of activating the matriptase, a serine protease with an important role in tissue remodeling [143], whose overexpression found in breast cancer tissue is associated with a poor prognosis [144] through activation of PAR-2-NF-KB and PI3K-Akt-mTOR, pro-inflammatory and pro-oncogenic signaling, respectively [145]. Likewise, matriptase has been implicated in invasiveness and metastasis in prostate cancer [146,147]. Recently, M69 antibody has been employed in TNBC cells with overexpressed matriptase [148] indicating that this S1P-activated enzyme has an important role on breast cancer therapy.

\section{Role of Ceramides in Chemoresistance}

Ceramides have been proposed as key regulatory molecules in breast cancer chemoresistance, being even considered as sensitizers to chemotherapy. The poor response in chemotherapy is a phenomenon commonly observed in breast cancer, however, is exacerbated in TNBC cells, a breast cancer subtype with a poor prognosis $[149,150]$. Several cell pathways have been proposed as triggers of neoplastic processes in TNBC, such as CD73, CD133, IMP3, ABCG2, HSF1 and PI3K/AKT/mTOR [150-155]. In breast cancer patients studied by Che J., et al., it has been found that after exposition to doxorubicin, cyclophosphamide, fluorouracil or its combination, ceramides levels decreased, indicating that its down-regulation is a common intrinsic response against breast cancer chemotherapy [20]. This subside response of ceramides concentration was determined in mammary tumor tissue, while in untreated women the levels remain unchanged [5]. Specific enzymes of ceramide metabolism have been characterized, UDP-glucose ceramide glucosyltransferase (UGCG) levels were higher after exposition to chemotherapeutic agents as doxorubicin, which lead to decreased ceramide levels [148]. Thus, specific inhibition of UGCG led to higher ceramide levels and this enhanced the sensitivity to doxorubicin and cyclophosphamide in MDA-MB-231 cells [20]. Zhang X. et al., reported that doxorubicin treatment induced the expression of UGCG in MCF-7 cells, an estrogen receptor $(E R \alpha)$ positive model, while this phenomenon is absent in MDA-MB-231 (ER $\alpha$ negative), suggesting an association between the ER $\alpha$ and the UGCG [156].

Moreover, UGCG is involved in multidrug resistance processes, especially in breast and colon cancer $[157,158]$. For instance, in one study the effects of UGCG on multidrug resistance protein 1 (MDR1) levels was characterized, which concluded that UGCG, specifically Gb3 and Gb4 up-regulates expression of MDR1 through $\beta$-catenin signaling, granting doxorubicin and paclitaxel resistance to murine breast cancer cells [159]. In addition, hyper-methylation of $\mathrm{CpG}$ islands in $5^{\prime}$ regions of UGCG promoter leads to its inhibition and subsequently to a major sensitivity to chemotherapy in breast cancer cells. In this investigation, authors demonstrated that methylation of UGCG promoter is performed by DNA methyltransferases (DNMTs). The UGCG promoter can be demethylated after the effect of DNMTs inhibitor 5-Aza-dc (Azacitidine), which has been used for therapy at hematological neoplastic processes, indicating the direct relationship between UGCG methylation and cell chemo-sensitivity [160]. 
Tamoxifen treatments have been reported to increase levels of C16, dHC16, C18, C20, dHC20, dHC22 ceramides in 4T1, MCF-7 and MDA-MB-231 cells, processes accompanied to JNK phosphorylation, caspase-3 and PARP cleavage, both conditions known as markers for cell death, suggesting that tamoxifen also induces cell death in a ceramide-dependent manner [161]. Moreover, tamoxifen shows an antagonist effect over P-gp, a protein with a flippase activity which transports glucosylceramides into Golgi lumen, and this inhibition results in a decreased ceramide glycosylation that leads to increased ceramide levels. Likewise, inhibition of the activity of acid ceramidase by tamoxifen has been reported. Therefore, tamoxifen effects on activation of cell death markers, diminution of ceramide glycosylation, and acid ceramidase inhibition explain its role at enhancing sensitivity to chemotherapy in breast cancer cells [162]. In addition, RIP2, an important mediator of innate immunity, has been recently studied as a modulator of breast cancer survival by Jafaar R., et al., whose results indicate that this kinase confers resistance to ceramide-induced apoptosis in triple-negative breast cancer cells treated with paclitaxel [163]. Thus, RIP2 inhibition can be proposed as a novel target to improve ceramide-induced apoptosis and then, a better antineoplastic drugs response.

\section{Final Considerations}

Ceramides are a species of sphingolipids whose functions have become relevant due to their various intracellular and signaling functions, some of them involved in pathological processes. Sphingolipid metabolism presents moonlighting effects on neoplastic processes due to its multiple metabolites, for instance ceramides being the proapoptotic intermediates, glucosylceramides the inducers of chemoresistance, and S1P the mitogenic sphingolipid [162]. Thus, it is critical to deepen the knowledge about why the increase in ceramides during initial stages of oncogenic processes favors the survival of the tumoral cells, but later becomes cytotoxic, opposed to the early phases. Evidence suggests that ceramide metabolism is associated with the efficacy of breast cancer therapeutics, several reports have evaluated the possibility to use ceramides as a vehicle in cancer treatments. Therefore, a better understanding of the mechanisms by which sphingolipids regulate cancer cell signaling and metabolism will improve the development of therapeutics.

The aim of this work was to describe an integral relationship between ceramide metabolism and breast cancer development and progression, highlighting its importance in the modulation of key processes such as apoptosis, proliferation, EMT, migration, invasion, and metastasis, resulting in a highly comprehensive and novel work that contributes to the better understanding of tumor ceramides metabolism. Therefore, this work represents a new approach to mechanisms that trigger cancer development and the role of ceramides.

Ceramides function on cell apoptosis has been demonstrated, then these lipids are closely related to mitochondrial structure alterations, facilitating the flow of pro-apoptotic proteins from the intermembrane space into the cytoplasm; also, they exert intracellular effects on insulin signaling induced by meta-inflammation. Therefore, ceramides can be visualized as a hub in the cellular metabolism by functioning as molecules with dual roles, as under stress conditions, which lead to inflammation, they regulate several functions such as apoptosis, and even subtle phenomena in the regulation of cellular cancer signaling mechanisms. The specific conditions in which these lipids will become pathological molecules is a subject pending elucidation.

Author Contributions: Conceived the idea: V.G.-G. and O.G.-H. Wrote the manuscript: V.G.-G., I.M.-N., J.F.D.-V., O.G.-H., G.H.-U. and A.A.P-A. Figures preparation: I.M.-N., J.F.D.-V., O.G.-H., G.H.-U. and A.A.P-A. Critically reviewed manuscript and figures: V.G.-G., J.F.D.-V. and O.G.-H. All authors approved the final manuscript.

Funding: This study was supported by Coordinación de Posgrado e Investigación-UABC grant 106/2/N/57/1 (1983), Convocatoria Especial para PTC 2015/2016 UABC grant 1984, PRODEP UABC-PTC-487, and XVI Convocatoria de Apoyo a la Movilidad Académica 2018-ID1286.

Acknowledgments: The authors recognize the helpful contribution of Gisel Ivonne Aceves-Franco, who critically reviewed and edited the manuscript, and José Antonio Uribe Vizcarra for contribution in the design of graphical abstract. 
Conflicts of Interest: The authors declare no conflict of interest.

\section{Abbreviations}

\begin{tabular}{|c|c|}
\hline ER & Endoplasmic reticulum \\
\hline FFA & Free fatty Acids \\
\hline SFA & Saturated Fatty Acids \\
\hline ECT & Electron transport chain \\
\hline ROS & Reactive oxygen specie \\
\hline DAGs & Diacylglycerols \\
\hline INSR & Insulin receptor \\
\hline SPT & Serin-palmitoyl acyltransferase \\
\hline CerS & Ceramide synthase \\
\hline NLRP3 & NOD-like receptor family pyrin domain containing 3 \\
\hline MVEs & Multivesicular endosome \\
\hline ESCRT-I & Endosomal sorting complex required for transport \\
\hline OMM & Outer mitochondrial membrane \\
\hline DES & Dihydroceramide desaturase \\
\hline CERT & Ceramide transfer protein \\
\hline SMase & Sphingomyelinase \\
\hline UPR & Unfolded protein response \\
\hline PACS-2 & Phosphofurin acidic cluster sorting protein 2 \\
\hline IMM & Inner mitochondrial membrane \\
\hline ERO- $1 \alpha$ & Endoplasmic reticulum oxidoreductase- 1 alpha \\
\hline PD-L1 & Programmed cell death-ligand 1 \\
\hline PAC-1 & Compound 1 activator of procaspase \\
\hline Mcl-1 & Myeloid cell leukemia-1 Mcl-1 \\
\hline VDAC-1 & Voltage-dependent anion-selective channel 1 \\
\hline $\mathrm{H} 2 \mathrm{~K}$ & Hexokinase-2 \\
\hline GPCR & G Protein-coupled receptor \\
\hline S1P & Sphingosine-1-phosphate \\
\hline SphK & Sphingosine kinase \\
\hline EMT & Epithelial-mesenchymal transition \\
\hline CK & Cytokeratin \\
\hline $\mathrm{Gg} 4$ & Galp $\beta 1-3$ GalpNAc $\beta 1-4$ Galp $\beta 1-4$ Glcp $\beta$ \\
\hline TNBC & Triple negative breast cancer \\
\hline EGF & Epidermal growth factor \\
\hline $\operatorname{Er} \alpha$ & Estrogen receptor \\
\hline UGCG & UDP-glucose ceramide glucosyltransferase \\
\hline 5-Aza-dc & Azacitidine \\
\hline MAMs & Mitochondria-associated ER membranes \\
\hline MDR1 & Multidrug resistance protein 1 \\
\hline DNMTs & DNA methyltransferases \\
\hline
\end{tabular}

\section{References}

1. Acosta-Montano, P.; Garcia-Gonzalez, V. Effects of dietary fatty acids in pancreatic beta cell metabolism, implications in homeostasis. Nutrients 2018, 10, 393. [CrossRef] [PubMed]

2. Chavez, J.A.; Summers, S.A. Characterizing the effects of saturated fatty acids on insulin signaling and ceramide and diacylglycerol accumulation in 3T3-L1 adipocytes and C2C12 myotubes. Arch. Biochem. Biophys. 2003, 419, 101-109. [CrossRef] [PubMed]

3. Gudz, T.I.; Tserng, K.Y.; Hoppel, C.L. Direct inhibition of mitochondrial respiratory chain complex III by cell-permeable ceramide. J. Biol. Chem. 1997, 272, 24154-24158. [CrossRef] [PubMed] 
4. Pinton, P.; Ferrari, D.; Rapizzi, E.; Di Virgilio, F.; Pozzan, T.; Rizzuto, R. The Ca ${ }^{2+}$ concentration of the endoplasmic reticulum is a key determinant of ceramide-induced apoptosis: Significance for the molecular mechanism of Bcl-2 action. EMBO J. 2001, 20, 2690-2701. [CrossRef] [PubMed]

5. Amati, F.; Dube, J.J.; Alvarez-Carnero, E.; Edreira, M.M.; Chomentowski, P.; Coen, P.M.; Switzer, G.E.; Bickel, P.E.; Stefanovic-Racic, M.; Toledo, F.G.; et al. Skeletal muscle triglycerides, diacylglycerols, and ceramides in insulin resistance: Another paradox in endurance-trained athletes? Diabetes 2011, 60, 2588-2597. [CrossRef] [PubMed]

6. Chung, J.O.; Koutsari, C.; Blachnio-Zabielska, A.U.; Hames, K.C.; Jensen, M.D. Effects of meal ingestion on intramyocellular ceramide concentrations and fractional de novo synthesis in humans. Am. J. Physiol. Endocrinol. Metab. 2017. [CrossRef] [PubMed]

7. Engin, A.B. What Is Lipotoxicity? Adv. Exp. Med. Biol. 2017, 960, 197-220. [PubMed]

8. Turpin, S.M.; Nicholls, H.T.; Willmes, D.M.; Mourier, A.; Brodesser, S.; Wunderlich, C.M.; Mauer, J.; Xu, E.; Hammerschmidt, P.; Bronneke, H.S.; et al. Obesity-induced CerS6-dependent C16:0 ceramide production promotes weight gain and glucose intolerance. Cell Metab. 2014, 20, 678-686. [CrossRef] [PubMed]

9. Ter Horst, K.W.; Gilijamse, P.W.; Versteeg, R.I.; Ackermans, M.T.; Nederveen, A.J.; la Fleur, S.E.; Romijn, J.A.; Nieuwdorp, M.; Zhang, D.; Samuel, V.T.; et al. Hepatic diacylglycerol-associated protein kinase cepsilon translocation links hepatic steatosis to hepatic insulin resistance in humans. Cell Rep. 2017, 19, 1997-2004. [CrossRef] [PubMed]

10. Petersen, M.C.; Madiraju, A.K.; Gassaway, B.M.; Marcel, M.; Nasiri, A.R.; Butrico, G.; Marcucci, M.J.; Zhang, D.; Abulizi, A.; Zhang, X.M.; et al. Insulin receptor Thr1160 phosphorylation mediates lipid-induced hepatic insulin resistance. J. Clin. Investig. 2016, 126, 4361-4371. [CrossRef] [PubMed]

11. Shi, H.; Kokoeva, M.V.; Inouye, K.; Tzameli, I.; Yin, H.; Flier, J.S. TLR4 links innate immunity and fatty acid-induced insulin resistance. J. Clin. Investig. 2006, 116, 3015-3025. [CrossRef] [PubMed]

12. Vandanmagsar, B.; Youm, Y.H.; Ravussin, A.; Galgani, J.E.; Stadler, K.; Mynatt, R.L.; Ravussin, E.; Stephens, J.M.; Dixit, V.D. The NLRP3 inflammasome instigates obesity-induced inflammation and insulin resistance. Nat. Med. 2011, 17, 179-188. [CrossRef] [PubMed]

13. Ueda, N. Ceramide-induced apoptosis in renal tubular cells: A role of mitochondria and sphingosine-1-phoshate. Int. J. Mol. Sci. 2015, 16, 5076-5124. [CrossRef] [PubMed]

14. Trajkovic, K.; Hsu, C.; Chiantia, S.; Rajendran, L.; Wenzel, D.; Wieland, F.; Schwille, P.; Brugger, B.; Simons, M. Ceramide triggers budding of exosome vesicles into multivesicular endosomes. Science 2008, 319, 1244-1247. [CrossRef] [PubMed]

15. Morvan, J.; Rinaldi, B.; Friant, S. Pkh1/2-dependent phosphorylation of Vps27 regulates ESCRT-I recruitment to endosomes. Mol. Biol. Cell 2012, 23, 4054-4064. [CrossRef] [PubMed]

16. Kumar, D.; Gupta, D.; Shankar, S.; Srivastava, R.K. Biomolecular characterization of exosomes released from cancer stem cells: Possible implications for biomarker and treatment of cancer. Oncotarget 2015, 6, 3280-3291. [CrossRef] [PubMed]

17. Abou-Ghali, M.; Stiban, J. Regulation of ceramide channel formation and disassembly: Insights on the initiation of apoptosis. Saudi J. Biol. Sci. 2015, 22, 760-772. [CrossRef] [PubMed]

18. Ganesan, V.; Perera, M.N.; Colombini, D.; Datskovskiy, D.; Chadha, K.; Colombini, M. Ceramide and activated Bax act synergistically to permeabilize the mitochondrial outer membrane. Apoptosis 2010, 15, 553-562. [CrossRef] [PubMed]

19. Ponnusamy, S.; Meyers-Needham, M.; Senkal, C.E.; Saddoughi, S.A.; Sentelle, D.; Selvam, S.P.; Salas, A.; Ogretmen, B. Sphingolipids and cancer: Ceramide and sphingosine-1-phosphate in the regulation of cell death and drug resistance. Future Oncol. 2010, 6, 1603-1624. [CrossRef] [PubMed]

20. Che, J.; Huang, Y.; Xu, C.; Zhang, P. Increased ceramide production sensitizes breast cancer cell response to chemotherapy. Cancer Chemother. Pharmacol. 2017, 79, 933-941. [CrossRef] [PubMed]

21. Kumari, M.; Wang, X.; Lantier, L.; Lyubetskaya, A.; Eguchi, J.; Kang, S.; Tenen, D.; Roh, H.C.; Kong, X.; Kazak, L.; et al. IRF3 promotes adipose inflammation and insulin resistance and represses browning. J. Clin. Investig. 2016, 126, 2839-2854. [CrossRef] [PubMed]

22. Garcia-Gonzalez, V.; Gutierrez-Quintanar, N.; Mas-Oliva, J. The C-terminal Domain Supports a Novel Function for CETPI as a New Plasma Lipopolysaccharide-Binding Protein. Sci. Rep. 2015, 5, 16091. [CrossRef] [PubMed] 
23. Hanada, K.; Kumagai, K.; Tomishige, N.; Yamaji, T. CERT-mediated trafficking of ceramide. Biochim. Biophys. Acta 2009, 1791, 684-691. [CrossRef] [PubMed]

24. Leonardini, A.; D'Oria, R.; Incalza, M.A.; Caccioppoli, C.; Buccheri, V.A.; Cignarelli, A.; Paparella, D.; Margari, V.; Natalicchio, A.; Perrini, S.; et al. GLP-1 receptor activation inhibits palmitate induced apoptosis via ceramide in human cardiac progenitor cells. J. Clin. Endocrinol. Metab. 2017. [CrossRef] [PubMed]

25. Crivelli, S.M.; Paulus, A.; Markus, J.; Bauwens, M.; Berkes, D.; de Vries, H.E.; Mulder, M.T.; Walter, J.; Mottaghy, F.M.; Losen, M.; et al. Synthesis, radiosynthesis, and preliminary in vitro and in vivo evaluation of the fluorinated ceramide trafficking inhibitor (HPA-12) for brain applications. J. Alzheimers Dis. 2017, 60, 783-794. [CrossRef] [PubMed]

26. Mullen, T.D.; Hannun, Y.A.; Obeid, L.M. Ceramide synthases at the centre of sphingolipid metabolism and biology. Biochem. J. 2012, 441, 789-802. [CrossRef] [PubMed]

27. Kraveka, J.M.; Li, L.; Szulc, Z.M.; Bielawski, J.; Ogretmen, B.; Hannun, Y.A.; Obeid, L.M.; Bielawska, A. Involvement of dihydroceramide desaturase in cell cycle progression in human neuroblastoma cells. J. Biol. Chem. 2007, 282, 16718-16728. [CrossRef] [PubMed]

28. Raichur, S.; Wang, S.T.; Chan, P.W.; Li, Y.; Ching, J.; Chaurasia, B.; Dogra, S.; Ohman, M.K.; Takeda, K.; Sugii, S.; et al. CerS2 haploinsufficiency inhibits $\beta$-oxidation and confers susceptibility to diet-induced steatohepatitis and insulin resistance. Cell Metab. 2014, 20, 687-695. [CrossRef] [PubMed]

29. Jennemann, R.; Rabionet, M.; Gorgas, K.; Epstein, S.; Dalpke, A.; Rothermel, U.; Bayerle, A.; van der Hoeven, F.; Imgrund, S.; Kirsch, J.; et al. Loss of ceramide synthase 3 causes lethal skin barrier disruption. Hum. Mol. Genet. 2012, 21, 586-608. [CrossRef] [PubMed]

30. Kitatani, K.; Idkowiak-Baldys, J.; Hannun, Y.A. The sphingolipid salvage pathway in ceramide metabolism and signaling. Cell Signal. 2008, 20, 1010-1018. [CrossRef] [PubMed]

31. Takeda, S.; Mitsutake, S.; Tsuji, K.; Igarashi, Y. Apoptosis occurs via the ceramide recycling pathway in human HaCaT keratinocytes. J. Biochem. 2006, 139, 255-262. [CrossRef] [PubMed]

32. Miller, L.G., Jr.; Young, J.A.; Ray, S.K.; Wang, G.; Purohit, S.; Banik, N.L.; Dasgupta, S. Sphingosine toxicity in EAE and MS: Evidence for ceramide generation via serine-palmitoyltransferase activation. Neurochem. Res. 2017. [CrossRef] [PubMed]

33. Pagadala, M.; Kasumov, T.; McCullough, A.J.; Zein, N.N.; Kirwan, J.P. Role of ceramides in nonalcoholic fatty liver disease. Trends Endocrinol. Metab. 2012, 23, 365-371. [CrossRef] [PubMed]

34. Ardail, D.; Popa, I.; Bodennec, J.; Louisot, P.; Schmitt, D.; Portoukalian, J. The mitochondria-associated endoplasmic-reticulum subcompartment (MAM fraction) of rat liver contains highly active sphingolipid-specific glycosyltransferases. Biochem. J. 2003, 371, 1013-1019. [CrossRef] [PubMed]

35. Rizzuto, R.; Pinton, P.; Carrington, W.; Fay, F.S.; Fogarty, K.E.; Lifshitz, L.M.; Tuft, R.A.; Pozzan, T. Close contacts with the endoplasmic reticulum as determinants of mitochondrial $\mathrm{Ca}^{2+}$ responses. Science 1998, 280, 1763-1766. [CrossRef] [PubMed]

36. Csordas, G.; Renken, C.; Varnai, P.; Walter, L.; Weaver, D.; Buttle, K.F.; Balla, T.; Mannella, C.A.; Hajnoczky, G. Structural and functional features and significance of the physical linkage between ER and mitochondria. J. Cell Biol. 2006, 174, 915-921. [CrossRef] [PubMed]

37. Simmen, T.; Aslan, J.E.; Blagoveshchenskaya, A.D.; Thomas, L.; Wan, L.; Xiang, Y.; Feliciangeli, S.F.; Hung, C.H.; Crump, C.M.; Thomas, G. PACS-2 controls endoplasmic reticulum-mitochondria communication and Bid-mediated apoptosis. EMBO J. 2005, 24, 717-729. [CrossRef] [PubMed]

38. Samanta, S.; Stiban, J.; Maugel, T.K.; Colombini, M. Visualization of ceramide channels by transmission electron microscopy. Biochim. Biophys. Acta 2011, 1808, 1196-1201. [CrossRef] [PubMed]

39. Seervi, M.; Sobhan, P.K.; Joseph, J.; Ann Mathew, K.; Santhoshkumar, T.R. ERO1 $\alpha$-dependent endoplasmic reticulum-mitochondrial calcium flux contributes to ER stress and mitochondrial permeabilization by procaspase-activating compound-1 (PAC-1). Cell Death Dis. 2013, 4, e968. [CrossRef] [PubMed]

40. Urano, F.; Wang, X.; Bertolotti, A.; Zhang, Y.; Chung, P.; Harding, H.P.; Ron, D. Coupling of stress in the ER to activation of JNK protein kinases by transmembrane protein kinase IRE1. Science 2000, 287, 664-666. [CrossRef] [PubMed]

41. Hayashi, T.; Su, T.P. Sigma-1 receptor chaperones at the ER-mitochondrion interface regulate $\mathrm{Ca}^{2+}$ signaling and cell survival. Cell 2007, 131, 596-610. [CrossRef] [PubMed] 
42. Hsu, S.Y.; Kaipia, A.; Zhu, L.; Hsueh, A.J. Interference of BAD (Bcl-xL/Bcl-2-associated death promoter)-induced apoptosis in mammalian cells by 14-3-3 isoforms and P11. Mol. Endocrinol. 1997, 11, 1858-1867. [PubMed]

43. Morciano, G.; Marchi, S.; Morganti, C.; Sbano, L.; Bittremieux, M.; Kerkhofs, M.; Corricelli, M.; Danese, A.; Karkucinska-Wieckowska, A.; Wieckowski, M.R.; et al. Role of Mitochondria-associated ER membranes in calcium regulation in cancer-specific settings. Neoplasia 2018, 20, 510-523. [CrossRef] [PubMed]

44. Betz, C.; Stracka, D.; Prescianotto-Baschong, C.; Frieden, M.; Demaurex, N.; Hall, M.N. Feature article: MTOR complex 2-Akt signaling at mitochondria-associated endoplasmic reticulum membranes (MAM) regulates mitochondrial physiology. Proc. Natl. Acad. Sci. USA 2013, 110, 12526-12534. [CrossRef] [PubMed]

45. Myhill, N.; Lynes, E.M.; Nanji, J.A.; Blagoveshchenskaya, A.D.; Fei, H.; Carmine Simmen, K.; Cooper, T.J.; Thomas, G.; Simmen, T. The subcellular distribution of calnexin is mediated by PACS-2. Mol. Biol. Cell 2008, 19, 2777-2788. [CrossRef] [PubMed]

46. Lynes, E.M.; Raturi, A.; Shenkman, M.; Ortiz Sandoval, C.; Yap, M.C.; Wu, J.; Janowicz, A.; Myhill, N.; Benson, M.D.; Campbell, R.E.; et al. Palmitoylation is the switch that assigns calnexin to quality control or $\mathrm{ER} \mathrm{Ca}^{2+}$ signaling. J. Cell Sci. 2013, 126, 3893-3903. [CrossRef] [PubMed]

47. Iwasawa, R.; Mahul-Mellier, A.L.; Datler, C.; Pazarentzos, E.; Grimm, S. Fis1 and Bap31 bridge the mitochondria-ER interface to establish a platform for apoptosis induction. EMBO J. 2011, 30, 556-568. [CrossRef] [PubMed]

48. Breckenridge, D.G.; Stojanovic, M.; Marcellus, R.C.; Shore, G.C. Caspase cleavage product of BAP31 induces mitochondrial fission through endoplasmic reticulum calcium signals, enhancing cytochrome c release to the cytosol. J. Cell Biol. 2003, 160, 1115-1127. [CrossRef] [PubMed]

49. Diaz-Villanueva, J.F.; Diaz-Molina, R.; Garcia-Gonzalez, V. Protein folding and mechanisms of proteostasis. Int. J. Mol. Sci. 2015, 16, 17193-17230. [CrossRef] [PubMed]

50. Kogot-Levin, A.; Saada, A. Ceramide and the mitochondrial respiratory chain. Biochimie 2014, 100, 88-94. [CrossRef] [PubMed]

51. Bernardi, P.; Scorrano, L.; Colonna, R.; Petronilli, V.; di Lisa, F. Mitochondria and cell death. Mechanistic aspects and methodological issues. Eur. J. Biochem. 1999, 264, 687-701. [CrossRef] [PubMed]

52. Siskind, L.J.; Davoody, A.; Lewin, N.; Marshall, S.; Colombini, M. Enlargement and contracture of C2-ceramide channels. Biophys. J. 2003, 85, 1560-1575. [CrossRef]

53. Lee, H.; Rotolo, J.A.; Mesicek, J.; Penate-Medina, T.; Rimner, A.; Liao, W.C.; Yin, X.; Ragupathi, G.; Ehleiter, D.; Gulbins, E.; et al. Mitochondrial ceramide-rich macrodomains functionalize Bax upon irradiation. PLoS ONE 2011, 6, e19783. [CrossRef] [PubMed]

54. Artetxe, I.; Ugarte-Uribe, B.; Gil, D.; Valle, M.; Alonso, A.; Garcia-Saez, A.J.; Goni, F.M. Does ceramide form channels? The ceramide-induced membrane permeabilization mechanism. Biophys. J. 2017, 113, 860-868. [CrossRef] [PubMed]

55. Colombini, M. Ceramide channels and their role in mitochondria-mediated apoptosis. Biochim. Biophys. Acta 2010, 1797, 1239-1244. [CrossRef] [PubMed]

56. Siskind, L.J.; Colombini, M. The lipids C2- and C16-ceramide form large stable channels. Implications for apoptosis. J. Biol. Chem. 2000, 275, 38640-38644. [CrossRef] [PubMed]

57. Stiban, J.; Fistere, D.; Colombini, M. Dihydroceramide hinders ceramide channel formation: Implications on apoptosis. Apoptosis 2006, 11, 773-780. [CrossRef] [PubMed]

58. Sentelle, R.D.; Senkal, C.E.; Jiang, W.; Ponnusamy, S.; Gencer, S.; Selvam, S.P.; Ramshesh, V.K.; Peterson, Y.K.; Lemasters, J.J.; Szulc, Z.M.; et al. Ceramide targets autophagosomes to mitochondria and induces lethal mitophagy. Nat. Chem. Biol. 2012, 8, 831-838. [CrossRef] [PubMed]

59. Tanida, I.; Ueno, T.; Kominami, E. LC3 and Autophagy. Methods Mol. Biol. 2008, 445, 77-88. [PubMed]

60. Bollinger, C.R.; Teichgraber, V.; Gulbins, E. Ceramide-enriched membrane domains. Biochim. Biophys. Acta 2005, 1746, 284-294. [CrossRef] [PubMed]

61. Hayashi, T.; Su, T.P. Intracellular dynamics of $\varepsilon-1$ receptors ( $\varepsilon-1$ binding sites) in NG108-15 cells. J. Pharmacol. Exp. Ther. 2003, 306, 726-733. [CrossRef] [PubMed]

62. Kutomi, G.; Tamura, Y.; Tanaka, T.; Kajiwara, T.; Kukita, K.; Ohmura, T.; Shima, H.; Takamaru, T.; Satomi, F.; Suzuki, Y.; et al. Human endoplasmic reticulum oxidoreductin 1- $\alpha$ is a novel predictor for poor prognosis of breast cancer. Cancer Sci. 2013, 104, 1091-1096. [CrossRef] [PubMed] 
63. Tanaka, T.; Kutomi, G.; Kajiwara, T.; Kukita, K.; Kochin, V.; Kanaseki, T.; Tsukahara, T.; Hirohashi, Y.; Torigoe, T.; Okamoto, Y.; et al. Cancer-associated oxidoreductase ERO1- $\alpha$ promotes immune escape through up-regulation of PD-L1 in human breast cancer. Oncotarget 2017, 8, 24706-24718. [CrossRef] [PubMed]

64. Van Vliet, A.R.; Giordano, F.; Gerlo, S.; Segura, I.; Van Eygen, S.; Molenberghs, G.; Rocha, S.; Houcine, A.; Derua, R.; Verfaillie, T.; et al. The ER Stress Sensor PERK Coordinates ER-Plasma Membrane Contact Site Formation through Interaction with Filamin-A and F-Actin Remodeling. Mol. Cell 2017, 65, 885-899. [CrossRef] [PubMed]

65. Blais, J.D.; Addison, C.L.; Edge, R.; Falls, T.; Zhao, H.; Wary, K.; Koumenis, C.; Harding, H.P.; Ron, D.; Holcik, M.; et al. Perk-dependent translational regulation promotes tumor cell adaptation and angiogenesis in response to hypoxic stress. Mol. Cell Biol. 2006, 26, 9517-9532. [CrossRef] [PubMed]

66. Teng, Y.; Ren, X.; Li, H.; Shull, A.; Kim, J.; Cowell, J.K. Mitochondrial ATAD3A combines with GRP78 to regulate the WASF3 metastasis-promoting protein. Oncogene 2016, 35, 333-343. [CrossRef] [PubMed]

67. Issop, L.; Fan, J.; Lee, S.; Rone, M.B.; Basu, K.; Mui, J.; Papadopoulos, V. Mitochondria-associated membrane formation in hormone-stimulated Leydig cell steroidogenesis: Role of ATAD3. Endocrinology 2015, 156, 334-345. [CrossRef] [PubMed]

68. Van Vliet, A.R.; Verfaillie, T.; Agostinis, P. New functions of mitochondria associated membranes in cellular signaling. Biochim. Biophys. Acta 2014, 1843, 2253-2262. [CrossRef] [PubMed]

69. Szymanski, J.; Janikiewicz, J.; Michalska, B.; Patalas-Krawczyk, P.; Perrone, M.; Ziolkowski, W.; Duszynski, J.; Pinton, P.; Dobrzyn, A.; Wieckowski, M.R. Interaction of mitochondria with the endoplasmic reticulum and plasma membrane in calcium homeostasis, lipid trafficking and mitochondrial structure. Int. J. Mol. Sci. 2017, 18, 1576. [CrossRef] [PubMed]

70. Karczmarek-Borowska, B.; Filip, A.; Wojcierowski, J.; Smolen, A.; Korobowicz, E.; Korszen-Pilecka, I.; Zdunek, M. Estimation of prognostic value of Bcl-xL gene expression in non-small cell lung cancer. Lung Cancer 2006, 51, 61-69. [CrossRef] [PubMed]

71. Malkinson, A.M. Molecular comparison of human and mouse pulmonary adenocarcinomas. Exp. Lung Res. 1998, 24, 541-555. [CrossRef] [PubMed]

72. Park, D.; Magis, A.T.; Li, R.; Owonikoko, T.K.; Sica, G.L.; Sun, S.Y.; Ramalingam, S.S.; Khuri, F.R.; Curran, W.J.; Deng, X. Novel small-molecule inhibitors of Bcl-xL to treat lung cancer. Cancer Res. 2013, 73, 5485-5496. [CrossRef] [PubMed]

73. Huang, H.; Shah, K.; Bradbury, N.A.; Li, C.; White, C. Mcl-1 promotes lung cancer cell migration by directly interacting with VDAC to increase mitochondrial $\mathrm{Ca}^{2+}$ uptake and reactive oxygen species generation. Cell Death Dis. 2014, 5, e1482. [CrossRef] [PubMed]

74. Patra, K.C.; Wang, Q.; Bhaskar, P.T.; Miller, L.; Wang, Z.; Wheaton, W.; Chandel, N.; Laakso, M.; Muller, W.J.; Allen, E.L.; et al. Hexokinase 2 is required for tumor initiation and maintenance and its systemic deletion is therapeutic in mouse models of cancer. Cancer Cell 2013, 24, 213-228. [CrossRef] [PubMed]

75. Wolf, A.; Agnihotri, S.; Micallef, J.; Mukherjee, J.; Sabha, N.; Cairns, R.; Hawkins, C.; Guha, A. Hexokinase 2 is a key mediator of aerobic glycolysis and promotes tumor growth in human glioblastoma multiforme. J. Exp. Med. 2011, 208, 313-326. [CrossRef] [PubMed]

76. Beckert, S.; Farrahi, F.; Aslam, R.S.; Scheuenstuhl, H.; Konigsrainer, A.; Hussain, M.Z.; Hunt, T.K. Lactate stimulates endothelial cell migration. Wound Repair Regen. 2006, 14, 321-324. [CrossRef] [PubMed]

77. Kim, J.W.; Tchernyshyov, I.; Semenza, G.L.; Dang, C.V. HIF-1-mediated expression of pyruvate dehydrogenase kinase: A metabolic switch required for cellular adaptation to hypoxia. Cell Metab. 2006, 3, 177-185. [CrossRef] [PubMed]

78. Papandreou, I.; Cairns, R.A.; Fontana, L.; Lim, A.L.; Denko, N.C. HIF-1 mediates adaptation to hypoxia by actively downregulating mitochondrial oxygen consumption. Cell Metab. 2006, 3, 187-197. [CrossRef] [PubMed]

79. Raturi, A.; Simmen, T. Where the endoplasmic reticulum and the mitochondrion tie the knot: The mitochondria-associated membrane (MAM). Biochim. Biophys. Acta 2013, 1833, 213-224. [CrossRef] [PubMed]

80. Bittremieux, M.; Parys, J.B.; Pinton, P.; Bultynck, G. ER functions of oncogenes and tumor suppressors: Modulators of intracellular $\mathrm{Ca}^{2+}$ signaling. Biochim. Biophys. Acta 2016, 1863, 1364-1378. [CrossRef] [PubMed] 
81. Ma, L.I.; Chang, Y.; Yu, L.; He, W.; Liu, Y. Pro-apoptotic and anti-proliferative effects of mitofusin-2 via PI3K/Akt signaling in breast cancer cells. Oncol. Lett. 2015, 10, 3816-3822. [CrossRef] [PubMed]

82. Herrera-Cruz, M.S.; Simmen, T. Cancer: Untethering mitochondria from the endoplasmic reticulum? Front. Oncol. 2017, 7, 105. [CrossRef] [PubMed]

83. Patergnani, S.; Missiroli, S.; Marchi, S.; Giorgi, C. Mitochondria-associated endoplasmic reticulum membranes microenvironment: Targeting autophagic and apoptotic pathways in cancer therapy. Front. Oncol. 2015, 5, 173. [CrossRef] [PubMed]

84. Bieberich, E. Ceramide signaling in cancer and stem cells. Future Lipidol. 2008, 3, 273-300. [CrossRef] [PubMed]

85. Morad, S.A.; Cabot, M.C. Ceramide-orchestrated signalling in cancer cells. Nat. Rev. Cancer 2013, 13, 51-65. [CrossRef] [PubMed]

86. Paschall, A.V.; Zimmerman, M.A.; Torres, C.M.; Yang, D.; Chen, M.R.; Li, X.; Bieberich, E.; Bai, A.; Bielawski, J.; Bielawska, A.; et al. Ceramide targets xIAP and cIAP1 to sensitize metastatic colon and breast cancer cells to apoptosis induction to suppress tumor progression. BMC Cancer 2014, 14, 24. [CrossRef] [PubMed]

87. Haynes, T.A.; Filippov, V.; Filippova, M.; Yang, J.; Zhang, K.; Duerksen-Hughes, P.J. DNA damage induces down-regulation of UDP-glucose ceramide glucosyltransferase, increases ceramide levels and triggers apoptosis in p53-deficient cancer cells. Biochim. Biophys. Acta 2012, 1821, 943-953. [CrossRef] [PubMed]

88. Zhang, X.; Li, B.; Zhang, Y.; Liu, J. Ceramide induces release of mitochondrial proapoptotic proteins in caspase-dependent and -independent manner in HT-29 cells. Sci. China Life Sci. 2008, 51, 66-71. [CrossRef] [PubMed]

89. Liu, Y.Y.; Hill, R.A.; Li, Y.T. Ceramide glycosylation catalyzed by glucosylceramide synthase and cancer drug resistance. Adv. Cancer Res. 2013, 117, 59-89. [PubMed]

90. Moro, K.; Kawaguchi, T.; Tsuchida, J.; Gabriel, E.; Qi, Q.; Yan, L.; Wakai, T.; Takabe, K.; Nagahashi, M. Ceramide species are elevated in human breast cancer and are associated with less aggressiveness. Oncotarget 2018, 9, 19874-19890. [CrossRef] [PubMed]

91. Roh, J.L.; Kim, E.H.; Park, J.Y.; Kim, J.W. Inhibition of glucosylceramide synthase sensitizes head and neck cancer to cisplatin. Mol. Cancer Ther. 2015, 14, 1907-1915. [CrossRef] [PubMed]

92. Roh, J.L.; Park, J.Y.; Kim, E.H.; Jang, H.J. Targeting acid ceramidase sensitises head and neck cancer to cisplatin. Eur. J. Cancer 2016, 52, 163-172. [CrossRef] [PubMed]

93. Henry, B.; Moller, C.; Dimanche-Boitrel, M.T.; Gulbins, E.; Becker, K.A. Targeting the ceramide system in cancer. Cancer Lett. 2013, 332, 286-294. [CrossRef] [PubMed]

94. Schiffmann, S.; Sandner, J.; Birod, K.; Wobst, I.; Angioni, C.; Ruckhaberle, E.; Kaufmann, M.; Ackermann, H.; Lotsch, J.; Schmidt, H.; et al. Ceramide synthases and ceramide levels are increased in breast cancer tissue. Carcinogenesis 2009, 30, 745-752. [CrossRef] [PubMed]

95. Nagahashi, M.; Tsuchida, J.; Moro, K.; Hasegawa, M.; Tatsuda, K.; Woelfel, I.A.; Takabe, K.; Wakai, T. High levels of sphingolipids in human breast cancer. J. Surg. Res. 2016, 204, 435-444. [CrossRef] [PubMed]

96. Flowers, M.; Fabrias, G.; Delgado, A.; Casas, J.; Abad, J.L.; Cabot, M.C. C6-ceramide and targeted inhibition of acid ceramidase induce synergistic decreases in breast cancer cell growth. Breast Cancer Res. Treat. 2012, 133, 447-458. [CrossRef] [PubMed]

97. Vethakanraj, H.S.; Babu, T.A.; Sudarsanan, G.B.; Duraisamy, P.K.; Ashok Kumar, S. Targeting ceramide metabolic pathway induces apoptosis in human breast cancer cell lines. Biochem. Biophys. Res. Commun. 2015, 464, 833-839. [CrossRef] [PubMed]

98. Ogretmen, B.; Hannun, Y.A. Biologically active sphingolipids in cancer pathogenesis and treatment. Nat. Rev. Cancer 2004, 4, 604-616. [CrossRef] [PubMed]

99. Guan, F.; Handa, K.; Hakomori, S.I. Specific glycosphingolipids mediate epithelial-to-mesenchymal transition of human and mouse epithelial cell lines. Proc. Natl. Acad. Sci. USA 2009, 106, 7461-7466. [CrossRef] [PubMed]

100. Ghosal, P.; Sukocheva, O.A.; Wang, T.; Mayne, G.C.; Watson, D.I.; Hussey, D.J. Effects of chemotherapy agents on Sphingosine-1-Phosphate receptors expression in MCF-7 mammary cancer cells. Biomed. Pharmacother. 2016, 81, 218-224. [CrossRef] [PubMed]

101. Bose, R.; Verheij, M.; Haimovitz-Friedman, A.; Scotto, K.; Fuks, Z.; Kolesnick, R. Ceramide synthase mediates daunorubicin-induced apoptosis: An alternative mechanism for generating death signals. Cell 1995, 82, 405-414. [CrossRef] 
102. Kim, E.S.; Kim, J.S.; Kim, S.G.; Hwang, S.; Lee, C.H.; Moon, A. Sphingosine 1-phosphate regulates matrix metalloproteinase-9 expression and breast cell invasion through S1P3-G $\alpha$ q coupling. J. Cell Sci. 2011, 124, 2220-2230. [CrossRef] [PubMed]

103. Lamouille, S.; Xu, J.; Derynck, R. Molecular mechanisms of epithelial-mesenchymal transition. Nat. Rev. Mol. Cell Biol. 2014, 15, 178-196. [CrossRef] [PubMed]

104. Nistico, P.; Bissell, M.J.; Radisky, D.C. Epithelial-mesenchymal transition: General principles and pathological relevance with special emphasis on the role of matrix metalloproteinases. Cold Spring Harb. Perspect. Biol. 2012, 4, a011908. [CrossRef] [PubMed]

105. Mathow, D.; Chessa, F.; Rabionet, M.; Kaden, S.; Jennemann, R.; Sandhoff, R.; Grone, H.J.; Feuerborn, A. Zeb1 affects epithelial cell adhesion by diverting glycosphingolipid metabolism. EMBO Rep. 2015, 16, 321-331. [CrossRef] [PubMed]

106. Edmond, V.; Dufour, F.; Poiroux, G.; Shoji, K.; Malleter, M.; Fouque, A.; Tauzin, S.; Rimokh, R.; Sergent, O.; Penna, A.; et al. Downregulation of ceramide synthase- 6 during epithelial-to-mesenchymal transition reduces plasma membrane fluidity and cancer cell motility. Oncogene 2015, 34, 996-1005. [CrossRef] [PubMed]

107. Levy, M.; Futerman, A.H. Mammalian ceramide synthases. IUBMB Life 2010, 62, 347-356. [CrossRef] [PubMed]

108. Bleicher, R.J.; Cabot, M.C. Glucosylceramide synthase and apoptosis. Biochim. Biophys. Acta 2002, 1585, 172-178. [CrossRef]

109. Grosch, S.; Schiffmann, S.; Geisslinger, G. Chain length-specific properties of ceramides. Prog. Lipid Res. 2012, 51, 50-62. [CrossRef] [PubMed]

110. Bornancin, F. Ceramide kinase: The first decade. Cell Signal. 2011, 23, 999-1008. [CrossRef] [PubMed]

111. Gomez-Munoz, A. Ceramide 1-phosphate/ceramide, a switch between life and death. Biochim. Biophys. Acta 2006, 1758, 2049-2056. [CrossRef] [PubMed]

112. Kim, C.W.; Lee, H.M.; Lee, T.H.; Kang, C.; Kleinman, H.K.; Gho, Y.S. Extracellular membrane vesicles from tumor cells promote angiogenesis via sphingomyelin. Cancer Res. 2002, 62, 6312-6317. [PubMed]

113. Paik, J.H.; Chae, S.; Lee, M.J.; Thangada, S.; Hla, T. Sphingosine 1-phosphate-induced endothelial cell migration requires the expression of EDG-1 and EDG-3 receptors and Rho-dependent activation of $\alpha \mathrm{v} \beta 3$ and $\beta 1$-containing integrins. J. Biol. Chem. 2001, 276, 11830-11837. [CrossRef] [PubMed]

114. Wang, F.; Van Brocklyn, J.R.; Hobson, J.P.; Movafagh, S.; Zukowska-Grojec, Z.; Milstien, S.; Spiegel, S. Sphingosine 1-phosphate stimulates cell migration through a Gi-coupled cell surface receptor. Potential involvement in angiogenesis. J. Biol. Chem. 1999, 274, 35343-35350. [CrossRef] [PubMed]

115. Haakenson, J.K.; Khokhlatchev, A.V.; Choi, Y.J.; Linton, S.S.; Zhang, P.; Zaki, P.M.; Fu, C.; Cooper, T.K.; Manni, A.; Zhu, J.; et al. Lysosomal degradation of CD44 mediates ceramide nanoliposome-induced anoikis and diminished extravasation in metastatic carcinoma cells. J. Biol. Chem. 2015, 290, 8632-8643. [CrossRef] [PubMed]

116. Sarkar, S.; Maceyka, M.; Hait, N.C.; Paugh, S.W.; Sankala, H.; Milstien, S.; Spiegel, S. Sphingosine kinase 1 is required for migration, proliferation and survival of MCF-7 human breast cancer cells. FEBS Lett. 2005, 579, 5313-5317. [CrossRef] [PubMed]

117. Sukocheva, O.; Wadham, C.; Holmes, A.; Albanese, N.; Verrier, E.; Feng, F.; Bernal, A.; Derian, C.K.; Ullrich, A.; Vadas, M.A.; et al. Estrogen transactivates EGFR via the sphingosine 1-phosphate receptor Edg-3: The role of sphingosine kinase-1. J. Cell Biol. 2006, 173, 301-310. [CrossRef] [PubMed]

118. Fan, S.H.; Wang, Y.Y.; Lu, J.; Zheng, Y.L.; Wu, D.M.; Zhang, Z.F.; Shan, Q.; Hu, B.; Li, M.Q.; Cheng, W. CERS2 suppresses tumor cell invasion and is associated with decreased V-ATPase and MMP-2/MMP-9 activities in breast cancer. J. Cell Biochem. 2015, 116, 502-513. [CrossRef] [PubMed]

119. Van Brocklyn, J.R.; Young, N.; Roof, R. Sphingosine-1-phosphate stimulates motility and invasiveness of human glioblastoma multiforme cells. Cancer Lett. 2003, 199, 53-60. [CrossRef]

120. Wu, H.X.; Wang, G.M.; Lu, X.; Zhang, L. miR-542-3p targets sphingosine-1-phosphate receptor 1 and regulates cell proliferation and invasion of breast cancer cells. Eur. Rev. Med. Pharmacol. Sci. 2017, 21, 108-114. [PubMed]

121. Filipenko, I.; Schwalm, S.; Reali, L.; Pfeilschifter, J.; Fabbro, D.; Huwiler, A.; Zangemeister-Wittke, U. Upregulation of the S1P3 receptor in metastatic breast cancer cells increases migration and invasion by induction of PGE2 and EP2/EP4 activation. Biochim. Biophys. Acta 2016, 1861, 1840-1851. [CrossRef] [PubMed] 
122. Gril, B.; Paranjape, A.N.; Woditschka, S.; Hua, E.; Dolan, E.L.; Hanson, J.; Wu, X.; Kloc, W.; Izycka-Swieszewska, E.; Duchnowska, R.; et al. Reactive astrocytic S1P3 signaling modulates the blood-tumor barrier in brain metastases. Nat. Commun. 2018, 9, 2705. [CrossRef] [PubMed]

123. Hu, W.; Tan, C.; He, Y.; Zhang, G.; Xu, Y.; Tang, J. Functional miRNAs in breast cancer drug resistance. OncoTargets Ther. 2018, 11, 1529-1541. [CrossRef] [PubMed]

124. Galindo-Hernandez, O.; Villegas-Comonfort, S.; Candanedo, F.; Gonzalez-Vazquez, M.C.; Chavez-Ocana, S.; Jimenez-Villanueva, X.; Sierra-Martinez, M.; Salazar, E.P. Elevated concentration of microvesicles isolated from peripheral blood in breast cancer patients. Arch. Med. Res. 2013, 44, 208-214. [CrossRef] [PubMed]

125. Galindo-Hernandez, O.; Gonzales-Vazquez, C.; Cortes-Reynosa, P.; Reyes-Uribe, E.; Chavez-Ocana, S.; Reyes-Hernandez, O.; Sierra-Martinez, M.; Salazar, E.P. Extracellular vesicles from women with breast cancer promote an epithelial-mesenchymal transition-like process in mammary epithelial cells MCF10A. Tumour Biol. 2015, 36, 9649-9659. [CrossRef] [PubMed]

126. Xu, J.; Camfield, R.; Gorski, S.M. The interplay between exosomes and autophagy_Partners in crime. J. Cell Sci. 2018, 131, jcs215210. [CrossRef] [PubMed]

127. Al-Nedawi, K.; Meehan, B.; Micallef, J.; Lhotak, V.; May, L.; Guha, A.; Rak, J. Intercellular transfer of the oncogenic receptor EGFRvIII by microvesicles derived from tumour cells. Nat. Cell Biol. 2008, 10, 619-624. [CrossRef] [PubMed]

128. Shedden, K.; Xie, X.T.; Chandaroy, P.; Chang, Y.T.; Rosania, G.R. Expulsion of small molecules in vesicles shed by cancer cells: Association with gene expression and chemosensitivity profiles. Cancer Res. 2003, 63, 4331-4337. [PubMed]

129. Safaei, R.; Larson, B.J.; Cheng, T.C.; Gibson, M.A.; Otani, S.; Naerdemann, W.; Howell, S.B. Abnormal lysosomal trafficking and enhanced exosomal export of cisplatin in drug-resistant human ovarian carcinoma cells. Mol. Cancer Ther. 2005, 4, 1595-1604. [CrossRef] [PubMed]

130. Rilla, K.; Mustonen, A.M.; Arasu, U.T.; Harkonen, K.; Matilainen, J.; Nieminen, P. Extracellular vesicles are integral and functional components of the extracellular matrix. Matrix Biol. 2017. [CrossRef] [PubMed]

131. Hoshino, A.; Costa-Silva, B.; Shen, T.L.; Rodrigues, G.; Hashimoto, A.; Tesic Mark, M.; Molina, H.; Kohsaka, S.; Di Giannatale, A.; Ceder, S.; et al. Tumour exosome integrins determine organotropic metastasis. Nature 2015, 527, 329-335. [CrossRef] [PubMed]

132. Weidle, U.H.; Dickopf, S.; Hintermair, C.; Kollmorgen, G.; Birzele, F.; Brinkmann, U. The role of micro RNAs in breast cancer metastasis: preclinical validation and potential therapeutic targets. Cancer Genom. Proteom. 2018, 15, 17-39.

133. Galindo-Hernandez, O.; Serna-Marquez, N.; Castillo-Sanchez, R.; Salazar, E.P. Extracellular vesicles from MDA-MB-231 breast cancer cells stimulated with linoleic acid promote an EMT-like process in MCF10A cells. Prostaglandins Leukot. Essent. Fatty Acids 2014, 91, 299-310. [CrossRef] [PubMed]

134. Choi, D.S.; Kim, D.K.; Kim, Y.K.; Gho, Y.S. Proteomics, transcriptomics and lipidomics of exosomes and ectosomes. Proteomics 2013, 13, 1554-1571. [CrossRef] [PubMed]

135. Record, M.; Carayon, K.; Poirot, M.; Silvente-Poirot, S. Exosomes as new vesicular lipid transporters involved in cell-cell communication and various pathophysiologies. Biochim. Biophys. Acta 2014, 1841, 108-120. [CrossRef] [PubMed]

136. El Buri, A.; Adams, D.R.; Smith, D.; Tate, R.J.; Mullin, M.; Pyne, S.; Pyne, N.J. The sphingosine 1-phosphate receptor 2 is shed in exosomes from breast cancer cells and is $\mathrm{N}$-terminally processed to a short constitutively active form that promotes extracellular signal regulated kinase activation and DNA synthesis in fibroblasts. Oncotarget 2018, 9, 29453-29467. [PubMed]

137. Karliner, J.S. Sphingosine kinase and sphingosine 1-phosphate in the heart: A decade of progress. Biochim. Biophys. Acta 2013, 1831, 203-212. [CrossRef] [PubMed]

138. Tran-Dinh, A.; Diallo, D.; Delbosc, S.; Varela-Perez, L.M.; Dang, Q.B.; Lapergue, B.; Burillo, E.; Michel, J.B.; Levoye, A.; Martin-Ventura, J.L.; et al. HDL and endothelial protection. Br. J. Pharmacol. 2013, 169, 493-511. [CrossRef] [PubMed]

139. Denimal, D.; Pais de Barros, J.P.; Petit, J.M.; Bouillet, B.; Verges, B.; Duvillard, L. Significant abnormalities of the HDL phosphosphingolipidome in type 1 diabetes despite normal HDL cholesterol concentration. Atherosclerosis 2015, 241, 752-760. [CrossRef] [PubMed]

140. Liu, M.; Seo, J.; Allegood, J.; Bi, X.; Zhu, X.; Boudyguina, E.; Gebre, A.K.; Avni, D.; Shah, D.; Sorci-Thomas, M.G.; et al. Hepatic apolipoprotein M (apoM) overexpression stimulates formation of 
larger apoM/sphingosine 1-phosphate-enriched plasma high density lipoprotein. J. Biol. Chem. 2014, 289, 2801-2814. [CrossRef] [PubMed]

141. Alemany, R.; van Koppen, C.J.; Danneberg, K.; Ter Braak, M.; Meyer Zu Heringdorf, D. Regulation and functional roles of sphingosine kinases. Naunyn Schmiedebergs Arch. Pharmacol. 2007, 374, 413-428. [CrossRef] [PubMed]

142. Jin, F.; Hagemann, N.; Sun, L.; Wu, J.; Doeppner, T.R.; Dai, Y.; Hermann, D.M. High-density lipoprotein (HDL) promotes angiogenesis via S1P3-dependent VEGFR2 activation. Angiogenesis 2018, 21, 381-394. [CrossRef] [PubMed]

143. Benaud, C.; Oberst, M.; Hobson, J.P.; Spiegel, S.; Dickson, R.B.; Lin, C.Y. Sphingosine 1-phosphate, present in serum-derived lipoproteins, activates matriptase. J. Biol. Chem. 2002, 277, 10539-10546. [CrossRef] [PubMed]

144. Kang, J.Y.; Dolled-Filhart, M.; Ocal, I.T.; Singh, B.; Lin, C.Y.; Dickson, R.B.; Rimm, D.L.; Camp, R.L. Tissue microarray analysis of hepatocyte growth factor/Met pathway components reveals a role for Met, matriptase, and hepatocyte growth factor activator inhibitor 1 in the progression of node-negative breast cancer. Cancer Res. 2003, 63, 1101-1105. [PubMed]

145. Sales, K.U.; Friis, S.; Konkel, J.E.; Godiksen, S.; Hatakeyama, M.; Hansen, K.K.; Rogatto, S.R.; Szabo, R.; Vogel, L.K.; Chen, W.; et al. Non-hematopoietic PAR-2 is essential for matriptase-driven pre-malignant progression and potentiation of ras-mediated squamous cell carcinogenesis. Oncogene 2015, 34, 346-356. [CrossRef] [PubMed]

146. Ko, C.J.; Huang, C.C.; Lin, H.Y.; Juan, C.P.; Lan, S.W.; Shyu, H.Y.; Wu, S.R.; Hsiao, P.W.; Huang, H.P.; Shun, C.T.; et al. Androgen-induced TMPRSS2 activates matriptase and promotes extracellular matrix degradation, prostate cancer cell invasion, tumor growth, and metastasis. Cancer Res. 2015, 75, 2949-2960. [CrossRef] [PubMed]

147. Tsai, C.H.; Teng, C.H.; Tu, Y.T.; Cheng, T.S.; Wu, S.R.; Ko, C.J.; Shyu, H.Y.; Lan, S.W.; Huang, H.P.; Tzeng, S.F.; et al. HAI-2 suppresses the invasive growth and metastasis of prostate cancer through regulation of matriptase. Oncogene 2014, 33, 4643-4652. [CrossRef] [PubMed]

148. Rather, G.M.; Lin, S.Y.; Lin, H.; Banach-Petrosky, W.; Hirshfield, K.M.; Lin, C.Y.; Johnson, M.D.; Szekely, Z.; Bertino, J.R. Activated matriptase as a target to treat breast cancer with a drug conjugate. Oncotarget 2018, 9 , 25983-25992. [CrossRef] [PubMed]

149. Wu, T.; Wang, X.; Li, J.; Song, X.; Wang, Y.; Zhang, L.; Li, Z.; Tian, J. Identification of personalized chemoresistance genes in subtypes of basal-like breast cancer based on functional differences using pathway analysis. PLoS ONE 2015, 10, e0131183. [CrossRef] [PubMed]

150. Schwentner, L.; Wolters, R.; Koretz, K.; Wischnewsky, M.B.; Kreienberg, R.; Rottscholl, R.; Wockel, A. Triple-negative breast cancer: The impact of guideline-adherent adjuvant treatment on survival-A retrospective multi-centre cohort study. Breast Cancer Res. Treat. 2012, 132, 1073-1080. [CrossRef] [PubMed]

151. Loi, S.; Pommey, S.; Haibe-Kains, B.; Beavis, P.A.; Darcy, P.K.; Smyth, M.J.; Stagg, J. CD73 promotes anthracycline resistance and poor prognosis in triple negative breast cancer. Proc. Natl. Acad. Sci. USA 2013, 110, 11091-11096. [CrossRef] [PubMed]

152. Elnashar, A.T.; Ali el, S.M.; Gaber, A. The prognostic value of triple negative in stage II/III breast cancer. J. Oncol. Pharm. Pract. 2012, 18, 68-75. [CrossRef] [PubMed]

153. Nadal, R.; Ortega, F.G.; Salido, M.; Lorente, J.A.; Rodriguez-Rivera, M.; Delgado-Rodriguez, M.; Macia, M.; Fernandez, A.; Corominas, J.M.; Garcia-Puche, J.L.; et al. CD133 expression in circulating tumor cells from breast cancer patients: Potential role in resistance to chemotherapy. Int. J. Cancer 2013, 133, 2398-2407. [CrossRef] [PubMed]

154. Desai, S.; Liu, Z.; Yao, J.; Patel, N.; Chen, J.; Wu, Y.; Ahn, E.E.; Fodstad, O.; Tan, M. Heat shock factor 1 (HSF1) controls chemoresistance and autophagy through transcriptional regulation of autophagy-related protein 7 (ATG7). J. Biol. Chem. 2013, 288, 9165-9176. [CrossRef] [PubMed]

155. Beelen, K.; Hoefnagel, L.D.; Opdam, M.; Wesseling, J.; Sanders, J.; Vincent, A.D.; van Diest, P.J.; Linn, S.C. $\mathrm{PI} 3 \mathrm{~K} / \mathrm{AKT} / \mathrm{mTOR}$ pathway activation in primary and corresponding metastatic breast tumors after adjuvant endocrine therapy. Int. J. Cancer 2014, 135, 1257-1263. [CrossRef] [PubMed]

156. Zhang, X.; Wu, X.; Su, P.; Gao, Y.; Meng, B.; Sun, Y.; Li, L.; Zhou, Z.; Zhou, G. Doxorubicin influences the expression of glucosylceramide synthase in invasive ductal breast cancer. PLoS ONE 2012, 7, e48492. [CrossRef] [PubMed] 
157. Gouaze, V.; Yu, J.Y.; Bleicher, R.J.; Han, T.Y.; Liu, Y.Y.; Wang, H.; Gottesman, M.M.; Bitterman, A.; Giuliano, A.E.; Cabot, M.C. Overexpression of glucosylceramide synthase and P-glycoprotein in cancer cells selected for resistance to natural product chemotherapy. Mol. Cancer Ther. 2004, 3, 633-639. [PubMed]

158. Gouaze-Andersson, V.; Yu, J.Y.; Kreitenberg, A.J.; Bielawska, A.; Giuliano, A.E.; Cabot, M.C. Ceramide and glucosylceramide upregulate expression of the multidrug resistance gene MDR1 in cancer cells. Biochim. Biophys. Acta 2007, 1771, 1407-1417. [CrossRef] [PubMed]

159. Liu, Y.Y.; Gupta, V.; Patwardhan, G.A.; Bhinge, K.; Zhao, Y.; Bao, J.; Mehendale, H.; Cabot, M.C.; Li, Y.T.; Jazwinski, S.M. Glucosylceramide synthase upregulates MDR1 expression in the regulation of cancer drug resistance through cSrc and $\beta$-catenin signaling. Mol. Cancer 2010, 9, 145. [CrossRef] [PubMed]

160. Liu, J.; Zhang, X.; Liu, A.; Zhang, D.; Su, Y.; Liu, Y.; You, D.; Yuan, L.; Kong, X.; Wang, X.; et al. Altered methylation of glucosylceramide synthase promoter regulates its expression and associates with acquired multidrug resistance in invasive ductal breast cancer. Oncotarget 2016, 7, 36755-36766. [CrossRef] [PubMed]

161. Bekele, R.T.; Venkatraman, G.; Liu, R.Z.; Tang, X.; Mi, S.; Benesch, M.G.; Mackey, J.R.; Godbout, R.; Curtis, J.M.; McMullen, T.P.; et al. Oxidative stress contributes to the tamoxifen-induced killing of breast cancer cells: Implications for tamoxifen therapy and resistance. Sci. Rep. 2016, 6, 21164. [CrossRef] [PubMed]

162. Morad, S.A.; Cabot, M.C. Tamoxifen regulation of sphingolipid metabolism-Therapeutic implications. Biochim. Biophys. Acta 2015, 1851, 1134-1145. [CrossRef] [PubMed]

163. Jaafar, R.; Mnich, K.; Dolan, S.; Hillis, J.; Almanza, A.; Logue, S.E.; Samali, A.; Gorman, A.M. RIP2 enhances cell survival by activation of NF-kB in triple negative breast cancer cells. Biochem. Biophys. Res. Commun. 2018, 497, 115-121. [CrossRef] [PubMed]

(C) 2018 by the authors. Licensee MDPI, Basel, Switzerland. This article is an open access article distributed under the terms and conditions of the Creative Commons Attribution (CC BY) license (http:/ / creativecommons.org/licenses/by/4.0/). 